MISCELÁNEA 



\title{
Dios, patria, rey y... contrabando. Tras las huellas del exilio monárquico portugués en España después de la derrota de la Monarquía del Norte (1919)
}

\author{
Alfredo Comesaña Paz
}

Doctorando en el Departamento de Historia Contemporánea, UNED

\section{God, country, king and... contraband. Traces of the Portuguese} royal exile in Spain after the end of the Monarchy North (1919)

\section{RESUMEN}

La caída de la Monarquía de los Braganza en Portugal dio lugar a un movimiento restauracionista que, en los años que siguieron a la instauración de la Primera República Portuguesa, desencadenaría numerosas revueltas, todas yuguladas por la República. En la última y más poderosa de ellas, desarrollada a principios de 1919 y denominada La Monarquía del Norte, tras la derrota,cientos de combatientes y sus dirigentes buscaron refugio en

España, configurando un colectivo que compuso un irrepetible cuadro social en la frontera hispano-lusa.

\section{PALABRAS CLAVE}

Monarquía, Portugal, movimiento realista, exilio realista portugués, España, Paiva Couceiro, D. Manuel, República Portuguesa.

\section{ABSTRACT}

The fall of the monarchy of Braganza in Portugal led to a restorationist movement, in the years following the establishment of the Portuguese First Republic, triggered numerous rebellions, all defeated by the Republic. In the latest and most powerful of them, developed in early 1919 and called The Monarchy North, after the defeat, hundreds of fighters and their leaders sought refuge in Spain, setting up a group that comprised a unique social picture in the border between Spain and Portugal.

\section{KEYWORKS}

Monarchy, Portugal, Royal movement, Portuguese royal exile, Spain, Paiva Couceiro, D. Manuel II, Portuguese Republic.

\section{LOS MONÁRQUICOS EN LOS PRIMEROS AÑOS DE LA PRIMERA} REPÚBLICA: DE LA RESIGNACIÓN A LA CONSPIRACIÓN (1910-1919)

La presencia de exiliados monárquicos portugueses en España, en el primer cuarto del siglo $\mathrm{XX}$, se remonta ya a los primeros meses que siguieron al estallido 
de la revolución del 5 de octubre de 1910 en Lisboa $^{1}$, que ponía término al reinado de Manuel II de Braganza y, por extensión, liquidaba el régimen monárquico en Portugal a la vez que fijaba el punto de partida de la malograda Primera República Portuguesa².

Las huestes manuelistas, que inicialmente en su gran mayoría recibieron el triunfo republicano con contenida resignación y sin apenas resistencia, pronto trocaron su pasividad por una actitud de resistencia cada vez más desafiante que incluía la vía insurreccional, además de la actividad partidaria, como medio para conseguir la restauración en el trono de los Braganza. Este cambio fue facilitado por la «deriva jacobina» que tomaba la República, tras el fracaso de los elementos moderados para implementar una política de «atração» ${ }^{3}$ que contribuyese a incorporar a la vida política republicana a los sectores monárquicos de la sociedad, excluidos por la intransigencia de la corriente más ortodoxa del Partido Republicano Portugués (PRP).

La llegada al poder de esta corriente del Partido Republicano Portugués, partidaria de iniciativas radicales para lograr una rápida modernización del país ${ }^{4}$, dio lugar a la aprobación de una serie de medidas que daban al traste con la política de reconciliación que pretendía el ala moderada del partido. Una de las decisiones de más profundo calado consistía en decretar una serie de iniciativas legislativas dirigidas a minorar el papel de preeminencia social que poseía en el país la Iglesia Católica.

Entre el paquete de leyes aprobado destacaba la célebre Ley de Separação do Estado e das Igrejas (abril 1911) ${ }^{5}$ que establecía severas limitaciones al culto

1 SERRA, João B., «O 5 de Outubro», en «História da Primeira República Portuguesa», Lisboa, Tinta da China, 2009, pág. 55 y siguientes.

2 La Primera República Portuguesa durante sus 16 años de duración (1910-1926) conoció tres grandes etapas:

- A República Velha (1910-1917): Caracterizada por la hegemonía del Partido Republicano Portugués (PRP), partido de tendencia izquierdista y laicista que capitalizaría el poder, rechazando asumir un rotativismo con las fuerzas conservadoras, siendo esta supremacía lo que arrastraría a republicanos conservadores a apoyar movimientos insurrecionales como único medio de acceso al poder.

- A República Nova (1917-1919): Breve etapa de gobierno presidencialista de tintes autoritarios bajo Sidónio Pais.

- A Nova República Velha (1919-1926): Última etapa republicana que conoció la vuelta del PRP, si bien hubo intentos fallidos reformistas para hacer viable el régimen republicano que finalmente acabaría a consecuencia de un golpe militar que instaurará una dictadura (Ditadura Nacional).

3 VALENTE, Vasco Pulido, «A República Velha (1910-1917)». Alêtheia Editores. Lisboa, 2010, pág. 14.

4 MARQUES, A. H. Oliveira «A primeira República portuguesa», Lisboa, Livros Horizonte, 1971, pág. 65-66.

${ }_{5}$ La autoría intelectual de la ley se debía a Afonso Costa que a través de 7 capítulos y 196 artículos desgranaba la quintaesencia de los principios que deberían de regir la política religiosa del régimen.

El artículo 2. condensaba el espíritu de la ley al afirmar que: «La religión apostólica romana deja de ser la religión del Estado»; quedaba a partir de ese momento rota la íntima ligazón entre Iglesia Católica y Estado, no sólo perdiendo la primera los privilegios que suponían el ser hasta el momento la religión del Estado, sino que este supeditaba al poder civil a la hasta entonces omnímoda Iglesia. 
católico así como la expropiación de los bienes del clero. Fue la chispa que prendió la mecha de la contrarrevolución monárquica entre los sectores sociales más tradicionalistas localizados en las zonas rurales, en especial en el septentrión luso, cuyo descontento fue aprovechado por los líderes realistas proclives a la sedición como medio de derribar a la República.

Fue así como se forjó entre un sector del monarquismo luso el caldo de cultivo social que dio lugar al estallido de numerosos movimientos conspirativos de carácter contrarrevolucionario ${ }^{6}$ con el objetivo primordial de derribar a la República poco tiempo después de que esta fuera instaurada. De entre estas tentativas

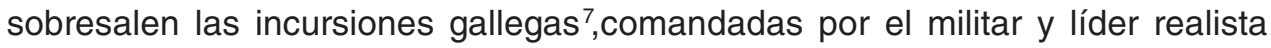
Paiva Couceiro ${ }^{8}$ en 1911 y 1912 , y las «outubradas» en 1913 y $1914^{9}$. Todas estas revueltas se saldaron con un estrepitoso fracaso para las armas monárquicas, que convencieron a D. Manuel que era inútil la vía conspirativa y se debía apostar por la vía política hasta el momento adecuado para dar un golpe de fuerza «desde arriba», y no hicieron más que nutrir las filas del colectivo de exiliados monárquicos que buscaban en la vecina España refugio, en especial en el sur de Gali-

Dicha subordinación eclesiástica al poder del Estado se desarrollaba en el articulado de la Ley: se fiscalizaba por parte del gobierno toda acción asociada al culto (horarios, financiación, recintos, actos...), con la prohibición expresa de realizar reuniones de carácter político en los recintos dedicados al culto (art. 50) o de celebrar cualquier acto religioso fuera de los lugares autorizados para ello sin la autorización de las autoridades (art. 55); se imponía la expropiación de las catedrales, iglesias y capillas (art. 62) que pasaban a ser de titularidad pública pero que a su vez eran cedidas a las corporaciones encargadas del culto (art. 89), dejando claro que siempre sería bajo el condicionante del cumplimiento de sus obligaciones con el Estado (art. 93)...

Se completaba esta inciativa legislativa para desterrar de la vida pública todo vestigio confesional, con la prohibición de la indumentaria religiosa fuera de los templos y los actos a celebrar (art. 176), la publicación de pastorales o cualquier notificación de la curia romana que no estuviese reportada al Ministerio de Justicia previamente (art. 181).

DE BRITO MOURA, María Lúcia. «A Guerra Religiosa na Primeira República». Editorial Noticias, 2004.

6 DIAS SANTOS, MIGUEL. «A Contra-Revolução na I República 1910-1919». Coimbra, Imprensa da Universidade de Coimbra, 2011.

TORRE GÓMEZ, Hipólito de la Col. con A. H. OLIVEIRA MARQUES, «Contrarrevolução. Documentos para a História da primeira república portuguesa, Perspectivas e Realidades», s. d., Lisboa, 1982.

7 Incursiones armadas lideradas por Paiva Couceiro, militar exiliado en España, llevadas a cabo desde Galicia en 1911 y 1912 (de ahí el nombre) desde donde cruzó el Miño con la esperanza de que en el septentrión lusitano la población y las guarniciones allí acantonadas se sumasen a la revuelta. Pero, mal organizadas y adiestradas y peor pertrechadas, serán fácilmente desbaratadas y puestas en fuga en dirección a España por las fuerzas republicanas regulares y los «Voluntarios da República», milicias compuestas por civiles republicanos comandados por oficiales del ejército surgidas como fuerza auxiliar en defensa de la República que serán la base de la despectivamente denominada «Formiga Branca» de los democráticos, cuyos milicianos serán utilizados para combatir a sus enemigos tanto de izquierda, sofocando manifestaciones y revueltas obreras y campesinas, como de derecha, colaborando en la lucha contra la insurgencia monárquica del norte del país.

8 RIBEIRO de MENESES, Luis Filipe, «Paiva Couceiro. Diários, Correspondência e Escritos Dispersos» Lisboa, Dom Quixote, 2011.

9 Las outubradas fueron movimientos insurreccionales de carácter monárquico que tuvieron lugar en los meses de octubre (de ahí su nombre) de 1913 y 1914. La primera fue abortada al ser detenidos los conspiradores antes de su estallido que estaba previsto que se produjese de forma simultánea en Lisboa y otras poblaciones. La segunda tuvo lugar el 20 de octubre de 1914 en Mafra con la sedición de un grupo de militares que fueron rápidamente derrotados por tropas fieles a la República. 
cia, huyendo de las autoridades republicanas. Estas por su parte, veían legitimada la política jacobina desarrollada por los diferentes gobiernos del PRP para acabar con los reaccionarios realistas en menoscabo de una salida pactada al conflicto social y político que se vivía en Portugal.

Sin embargo, si bien la República salió airosa de todos los golpes de mano de carácter monárquico organizados para liquidarla, los triunfos obtenidos no le reportaron los beneficios aparejados a la consecuente consolidación de su posición frente a la oposición monárquica ¿Por qué razón?

Porque la República no sólo debía hacer frente a la amenaza que suponía la contrarrevolución monárquica sino también a la debilidad interna que minaba los cimientos del régimen. Esta debilidad venía dada por la confrontación entre el gran partido republicano, el Partido Republicano Português, cuyo poder hegemónico en la escena política era tal que no ofrecía posibilidad alguna a los minoritarios partidos republicanos moderados y conservador (Partido Evolucionista y Partido da União Republicana) para una alternancia en el poder (sistema multipartidista de partido dominante $)^{10}$, viéndose abocados al eterno papel de opositores, en caso de respetar las normas del juego parlamentario vigentes, o a aceptar entrar en coalición en gabinetes dominados por el PRP, o bien recurrir a la solución conspirativa como única vía de alcanzar el poder, como sucedió a principios de 1915 con el apoyo a la breve experiencia autoritaria del general Pimenta de Castro.

Esta segunda vía se repitió con la revolución desencadenada en Lisboa el 5 de diciembre de 1917, una nueva revuelta, promovida por el republicanismo unionista e independiente, contra el gobierno democrático de Afonso Costa que, ante la tibieza del líder unionista Brito Camacho para asumir la jefatura, fue dirigida por Sidónio Pais ${ }^{11}$, hasta entonces una figura secundaria en la escena política pero que con su ímpetu consiguió desbancar del poder, tras tres días de dura lucha en las calles, al PRP. Para ello, Sidónio contó con el apoyo, no sólo de grupos civiles republicanos rivales de la Formiga Branca, sino también de buena parte de las clases populares urbanas lisboetas, unidos bajo el común denominador del rechazo al gobierno del PRP a quienes responsabilizaban de la difícil situación económica que vivía Portugal, víctima de las desastrosas consecuencias económicas de su beligerancia al lado de la Triple Entente en la Gran Guerra (escasez de artículos de primera necesidad, alza de precios, movilización y bajas de jóvenes alistados para el frente de batalla,...).

Con la revolución dezembrista se ponía fin al poder hegemónico del PRP mantenido desde 1911 a 1917, etapa conocida como República Velha, y daba co-

10 CASTRO LEAL, Ernesto. «Partidos e Programas. O campo partidário republicano português 19101926».Imprensa da Universidade de Coimbra. Coimbra, 2008, pág. 45

11 MALHEIRO DA SILVA, A. «Sidónio e Sidonismo». Vol. 1. Coimbra, Imprensa da Universidade de Coimbra, 2006, pág. 419. 
mienzo una nueva etapa para el régimen republicano: la República Nova, breve experiencia presidencialista bajo la batuta de Sidónio Pais.

¿Cómo vivió la hueste manuelina estos acontecimientos? Sin duda con aprobación, cuando no con abierta complacencia, pues la derrota del democratismo suponía un respiro a la presión que este ejercía sobre su colectivo, impidiendo una participación activa en la política, aplicando la Lei de Separação y purgando la administración pública y el ejército de elementos monárquicos a los que consideraban conspiradores en potencia ("La República era para los republicanos”) ${ }^{12}$.

Además se beneficiaban del nuevo rumbo que respecto a los intereses de los realistas tomaba el gobierno al aplicar una política más benigna y conciliadora que incluía generosas amnistías para los presos y exiliados que habían participado en las revueltas realistas (sin ir más lejos así sería posible que Paiva Couceiro retornase a Portugal de su exilio gallego), se suavizaban la aplicación de las leyes religiosas que tanto habían perjudicado a la Iglesia Católica, se permitían la creación de centros políticos monárquicos, facilitaban la difusión de sus periódicos y su participación activa en la vida parlamentaria a través de las elecciones, reintegraban a los funcionarios y militares depurados por su condición monárquica,... En una palabra, les era devuelto lo que el costismo les había arrebatado.

Durante el breve periodo del gobierno de corte presidencialista de Sidónio Pais, este trató de insuflar un aire renovador a la República a través de reformas de gran calado: implantación por primera vez en la historia del país del sufragio universal masculino, reforzamiento de los poderes de Presidente de la República en detrimento de las cámaras, restablecimiento de relaciones con el Vaticano (rotas tras la promulgación de la Lei de Separação) o disminuyendo el esfuerzo de guerra. Era el momento de la Idea $\mathrm{Nova}^{13}$, una nueva forma de enfocar el proyecto republicano en la que la nación estaría por encima de cualquier disputa sobre quién debería desempeñar la jefatura del Estado (rey o presidente) y que no entendía, por tanto, de rencillas entre portugueses. Se trataba de desmantelar las bases políticas sobre las que el PRP había gobernado durante los últimos años lo que también suponía el alejamiento de este partido de la vida pública, condenado al ostracismo político y con buena parte de su dirección exiliada.

Pero pronto la República Nova de Pais se vio acorralada por la creciente oposición mostrada por los republicanos del PRP y un movimiento obrero, que, si bien inicialmente le había apoyado para derribar el gobierno de Afonso Costa, ahora se encontraba desilusionado al no ver cumplidas sus expectativas. El resultado de tal situación fue el estallido de numerosas revueltas de carácter democrático y protestas obreras que culminaron con una huelga general en noviembre de 1918 que fueron duramente yuguladas.

12 VALENTE, V. Pulido. Op. cit. en nota (3). Pág. 31.

13 MALHEIRO DA SILVA, A. «Sidónio e Sidonismo». Vol. 2. Coimbra, Imprensa da Universidade de Coimbra, 2006, pág. 75. 
El sidonismo se vio obligado a recurrir a la presión policial para conseguir la tranquilidad en las calles y ciudades en permanente efervescencia y las cárceles comenzaron a llenarse con centenares de presos políticos condenados sin juicio previo. La deriva cada vez más autoritaria de la República Nova, donde Sidónio Pais gobernaba por decreto, casi al margen de un parlamento que controlaba, terminó haciéndole perder también el soporte político que tenía en el Partido Unionista y los machadistas (republicanos independientes) que no veían con buenos ojos el estado parapolicial en que se estaba convirtiendo el país.

Así, la República Nova hubo de depender cada vez más de su propio partido, el $\mathrm{PNR}^{14}$, de los monárquicos, católicos y de una parte importante de la oficialidad del ejército que con la guerra había ido adquiriendo un papel cada vez más activo en los asuntos de gobierno y que en los últimos meses de 1918, a imagen de las Juntas de Defensa españolas, comenzaban a organizarse en las denominadas Juntas Militares con una marcada inclinación a la injerencia en la política del país.

Los opositores no tardaron en tomar conciencia de que la única salida para provocar la caída de la República Nova pasaba por la eliminación física de Sidónio Pais, un recurso ya empleado para finiquitar a la Monarquía con el regicidio de Carlos I en $1908^{15}$. Después de algún intento fallido del que salió ileso, Sidónio Pais moría finalmente el 18 de diciembre víctima de un atentado ${ }^{16}$, al ser tiroteado por un republicano radical en la estación do Rosío cuando se disponía a viajar al norte para negociar con la recientemente creada Junta Militar del Norte y solventar la crisis que esta había desencadenado al comenzar a cuestionar la autoridad de la República, arrogándose funciones de gobierno en el norte del país.

Tras el vacío de poder creado con el magnicidio de Pais, la legislación que consagraba el régimen presidencialista y el sufragio universal fue revocada de un plumazo, volviéndose a aplicar la Constitución de 1911 en todos sus términos. Fue constituido un nuevo gobierno presidido por Tamagnini Barbosa y elegido por el parlamento (y no votado en elecciones como lo había sido Sidónio Pais) un nuevo Presidente de la República, puesto que recayó en el Almirante Canto e Castro (curiosamente de filiación monárquica). Los movimientos del nuevo gobierno exasperaron a los militares junteros y monárquicos a partes iguales, los primeros porque habían acordado con el difunto presidente que en caso de ser este eliminado 191.

14 TELO, José António. O sidonismo e o movimento operário português. Lisboa, Ulmeiro 1977, pág.

15 D. Carlos I, padre de D. Manuel, fue asesinado junto a su primogénito, el príncipe D. Luis, el 1 de febrero de 1908 en el Terreiro do Paço (la actual Praça do Comércio) de Lisboa cuando la familia real, compuesta por el rey, el príncipe heredero, la reina Doña Amelia y D. Manuel, se dirigía al Palacio Real en un coche de caballos descubierto. Los autores materiales del regicidio fueron dos republicanos (aunque se sospecha que formaban parte de un grupo más numeroso) que dispararon al rey y a los príncipes. Tras el intenso tiroteo el monarca murió allí mismo, D. Luis Felipe fue herido de gravedad y murió pocos minutos después del atentado y D. Manuel fue herido en un brazo pero sobrevivió y pasó así a ocupar el trono al ser el segundo en la línea de sucesión.

16 MALHEIRO DA SILVA, A. Op. cit.en nota (13), pág. 348. 
físicamente se constituiría un gobierno militar, cosa que no fue cumplida, y los segundos, además de por incumplir lo pactado con las Juntas Militares, porque veían un cambio de actitud hacia la odiada «demagogia», esto es, hacia los republicanos del PRP.

La muerte de Sidónio Pais fue recibida con una mezcla de indignación, pesar y alarmismo por los monárquicos que veían con la desaparición del líder indiscutible, del «Presidente-Rey» como lo denominó Pessoa, la cercanía del fin inexorable de la República Nova. Ante el nuevo giro que tomaban los acontecimientos, el sector oficialista del partido monárquico dirigido por Aires de Ornelas (representante de D. Manuel en Portugal) pretendía mantener la política de colaboración con los sidonistas que trataban de dar continuidad a la obra de su desaparecido líder. Pero para otro sector del monarquismo era el momento adecuado para intentar el asalto al poder pues, ante la amenaza de un retorno del PRP al poder, en los años transcurridos de régimen republicano nunca hasta entonces su posición había sido tan sólida, reocupando puestos de responsabilidad en la administración y siendo una notable parte de la oficialidad de las fuerzas armadas de filiación realista.

Entretanto, el nuevo gobierno de Tamagnini Barbosa trataba de satisfacer a unos y a otros. Por una parte, amnistiaba a los presos republicanos opositores al sidonismo; por otra parte, se avenía a modificar su gabinete dando entrada a nuevos ministros que contaban con el beneplácito de las Juntas militares que no dudaban en llegar al amago golpista, sacando las tropas a las calles de la capital. $Y$ como es habitual, esta política de apaciguamiento no hacía más que extremar los ánimos de unos y otros sin conseguir el sosiego deseado.

Fueron los republicanos democráticos, apoyados por republicanos independientes, los primeros en volver a intentar un golpe de mano contra el gobierno al considerar que, con su actitud claudicante hacia los militares, se facilitaba una dictadura o una vuelta de la monarquía. El 12 de enero de 1919 la intentona estalló en Lisboa pero, rápidamente sofocada por las tropas fieles al gobierno, los revolucionarios se trasladaron a Santarem desde donde intentaron continuar con la aventura revolucionaria. Sin embargo, la ciudad, sitiada por las tropas fieles al gobierno y sometida a fuego de artillería, no resistió y finalmente los rebeldes hubieron de rendirse.

La revuelta de Santarem fue la señal de alarma definitiva para que, los monárquicos proclives a un movimiento contrarrevolucionario, se convenciesen de que había llegado el momento de levantarse en armas contra una República que parecía caminar con paso firme a una vuelta, más pronto que tarde, del PRP al poder y con ello volvía a cernirse sobre el horizonte el peligro de una nueva etapa de persecución a la grey azul y blanca. Era el momento de actuar.

Desde Oporto un activo grupo de realistas del sector más proclive a la contrarrevolución, dirigido una vez más por Paiva Couceiro, comenzó a planificar un 
golpe contra el gobierno republicano, contando con el apoyo de buena parte de la oficialidad de las guarniciones norteñas afectas a la Junta Militar del Norte. La insurrección, que reventaría apenas una semana después de ser sofocada la de signo contrario de Santarem, pasaría a la Historia con el nombre de «La Monarquía del Norte».

\section{LA MONARQUÍA DEL NORTE (1919): EL CANTO DEL CISNE DEL MOVIMIENTO CONTRARREVOLUCIONARIO MONÁRQUICO LUSITANO}

Entre el 19 de enero y el 13 de febrero de 1919 se libró en Portugal una breve contienda civil conocida como «La Monarquía del Norte» ${ }^{17}$. Sería la última y más importante revuelta de carácter monárquico de todas las pergeñadas hasta la fecha contra la Primera República de Portugal y que supuso, al fin y a la postre, el canto del cisne de las aspiraciones de los seguidores del exiliado monarca, D. Manuel II ${ }^{18}$, para lograr la restauración en el trono de la dinastía de los Braganza. El epicentro de la insurrección se focalizó en el norte del país, donde mejor acogida social tenía un tradicionalismo forjado sobre la base triádica de Dios, Patria y Rey, siendo Oporto la capital de un efímero reino, controlado por los insurrectos realistas, que durante apenas 4 semanas controlaría el territorio comprendido entre los ríos Miño y Vouga. El fallido intento de extender la rebelión a Lisboa, una vez fueron derrotadas las unidades militares revoltosas junto a los civiles monárquicos en Monsanto ${ }^{19}$ por las fuerzas republicanas, precipitó el fin de la aventura sediciosa realista.

17 ALLEGRO, José Luciano Sollari, Para a História da Monarquía do Norte. Bertrand, 1988.

MOREIRA DA SILVA, Helena, «Monarquía do Norte. 1919». Colecção Guerras e campanhas militares da História de Portugal. Lisboa, 2008.

ROCHA MARTINS, A Monarquía do Norte. Gráficas «ABC». Lisboa, 1922.

18 El joven monarca había tenido que abandonar el trono de Portugal tras la Revolución del 5 de octubre de 1910, instalándose en Twickenham (Londres) desde donde dirigía los intereses de su causa, representada en Portugal por su Lugarteniente Ayres de Ornelas.

D. Manuel marcaba las directrices de la línea oficialista del monarquismo que mantenía el compromiso de colaborar con la República mientras no acabase la guerra y fuera firmada la Paz de París; una paz en la que se habían depositado grandes esperanzas por lo que consideraba de importancia vital para el país el no plantear disputas que lo desestabilizasen.

Por contra, existía un sector monárquico, muy activo en el norte, que consideraba finiquitado el compromiso con la República tras la muerte del presidente Sidónio Pais a finales de 1918 y defendía, ante el posible retorno del Partido Popular Republicano al poder, que era necesario acabar con la República a través de un movimiento insurreccional.

${ }^{19}$ La sierra de Monsanto, hoy parque forestal y el principal pulmón verde de Lisboa, se encuentra situada a las afueras de la capital desde la que se domina la ciudad. En 1919 poseía un fuerte y una estación de telégrafos; por razones aún no del todo aclaradas, las tropas y civiles monárquicos conjurados decidieron desplazarse y hacerse fuertes allí, conscientes que en las calles de la capital poco podían hacer ante el ímpetu de las milicias que estaba armando el gobierno y ante la actitud neutral de muchas unidades de la guarnición militar que no se decidían a tomar partido. La «escalada de Monsanto» se saldó, tras unas 48 horas de combates, con la derrota de los monárquicos y supuso, a la postre, la condena al fracaso de la Monarquía del Norte al no poder ser tomada Lisboa para las armas realistas. 
La Junta Gubernativa del Reino, que gobernaba de forma provisional en Oporto hasta que el ex soberano D. Manuel II retornase a Portugal, poco podía hacer para sostener una larga campaña militar contra el gobierno republicano que disponía de los cuantiosos recursos humanos, económicos y militares que le proporcionaba el dominio sobre más de dos tercios del país, incluyendo a la capital.

Aislada, incapaz de obtener el reconocimiento de beligerancia (en especial por parte de España y el Reino Unido), algo que resultaba fundamental para afrontar con expectativas de éxito una campaña militar que se aventuraba larga al haber contenido la República con éxito el primer embate contrarrevolucionario y que exigía disponer cuantiosos pertrechos y aprovisionamientos, la Junta Gubernativa del Reino vio como el proyecto restauracionista quedaba reducido a la nada. Y así, a las pocas semanas de la iniciarse la insurrección, el avance del ejército republicano era imparable, encontrándose cada vez más cerca de Oporto.

No fue necesario librar una cruenta batalla por la capital norteña. El 13 de febrero reventaba una rebelión en la capital del Duero, esta vez de signo republicano, en la que tras una breve resistencia se conseguía ganar la ciudad para la República, precipitando el fin de la Monarquía del Norte. Poco podían hacer los militares y civiles implicados en la rebelión más que huir al país vecino o enfrentarse a los tribunales que los juzgarían por alta traición. De nuevo Paiva Couceiro, y con él centenares de civiles y militares monárquicos derrotados, emprendían la huida buscando refugio en territorio español como lo habían hecho en anteriores revueltas malogradas.

\section{ZONAS DE ASENTAMIENTO Y ESTRUCTURA ORGANIZATIVA DEL EXILIO MONÁRQUICO PORTUGUÉS TRAS EL OCASO DE LA MONARQUÍA DEL NORTE}

Aquellos monárquicos que pudieron alcanzar la frontera española en febrero de 1919, tras el fin de la Monarquía del Norte, se resignaron a seguir los mismos pasos que habían dado años atrás los veteranos de las fracasadas incursiones gallegas de 1911 y 1912, lo que, entre otras cosas, implicaba perseverar en el compromiso de organizar nuevas tentativas conspirativas desde España. Por tanto, no resultaba novedoso para muchos de ellos la vuelta al exilio a la espera de tiempos mejores ni la existencia previa de una infraestructura creada por realistas portugueses en territorio español para acoger y prestar servicio a los evadidos que llegaban de Portugal, así como mantener su unidad de acción a través de una red de contactos entre las diferentes localidades en las que se cobijaron.

Este colectivo durante los próximos meses capitalizará en buena medida las relaciones bilaterales entre el Reino de España y la República de Portugal, dando lugar a conflictos en los que se veían envueltos en territorio español ciudadanos portugueses al servicio o simpatizantes del gobierno republicano. Estos hechos 
obligarán a que se vean implicados los responsables de las diplomacias de ambos países e incluso otros ministerios (como el Ministerio de Gobernación español o el Ministerio de la Guerra portugués) para tratar de solventar los problemas originados que ponían en riesgo las relaciones de buena vecindad entre ambas naciones.

Unas relaciones que en 1919 no pasaban por su mejor momento, pues en los años previos la cuestión del «peligro español» (apetencias anexionistas fundamentadas en el célebre irredentismo iberista, incluidas) había despertado recelos en la clase política y opinión pública portuguesa a raíz de las veleidades intervencionistas de la monarquía alfonsina en los asuntos internos de la República portuguesa. Injerencia que desde España se justificaba debido a la crónica inestabilidad que sufría Portugal, y que no había hecho más que empeorar debido a las consecuencias de su intervención en la Primera Guerra Mundial. Todo ello no había hecho más que tensar en momentos puntuales las relaciones entre las naciones vecinas.

Como veremos, los incidentes protagonizados por los emigrados portugueses que se pueden rastrear en los archivos españoles y portugueses trazan un fascinante mundo, en especial, en la «raia» (frontera) galaico-portuguesa (región miñota) a caballo entre el norte de Portugal y el sur de Galicia, donde se entrelazan episodios de violencia sectaria entre portugueses de distinto credo político, agentes informadores, contrabandismo, sobornos, tráfico de armas,... Hechos que conforman un interesante capítulo de la Historia reciente de Portugal y España que con este documento trataremos de contribuir a su rescate para la memoria colectiva de ambos pueblos.

Tras la derrota de los revoltosos norteños, el desarrollo de los acontecimientos en Portugal auguraba un más que probable retorno al poder del PRP. La liquidación de la República Nova con la caída del gabinete de Tamagnini Barbosa, provocada por el estallido de la Monarquía del Norte, había dado paso a una etapa de transición en la que los republicanos habían cerrado filas para la defensa del régimen, constituyendo un gobierno de concentración presidido por el independiente José Relvas con la inclusión de ministros de todo el espectro ideológico republicano (entre ellos 2 del PRP) con el objetivo primordial de yugular la revolución restauracionista. Conseguida la victoria de la República sobre los revoltosos norteños en febrero de 1919, los acontecimientos se precipitaron, y tal como se temía por parte de los opositores al democratismo, el PRP consiguió recuperar el control del gobierno de la República y adueñarse una vez más del poder (gobiernos de Domingos Pereira y Sá Cardoso). Quedaba inaugurada la última etapa de la República conocida como A Nova República Velha.

Sin embargo, a pesar del triunfo republicano sin paliativos sobre la Monarquía del Norte, no se podía considerar definitivamente desaparecida la amenaza contrarrevolucionaria que representaban los monárquicos ni tampoco el revanchismo del sidonismo puesto que los republicanos dezembristas, si bien en su mayoría 
habían luchado contra la Monarquía del Norte, no estaban dispuestos a aceptar de buen grado una vuelta del democratismo al poder, por lo que también pergeñaban sus propias maniobras para reeditar un nuevo 5 de diciembre. Es así como durante los meses que siguen a la caída de la Monarquía del Norte el problema que generaba la existencia de cientos de emigrados políticos portugueses en España, la mayoría establecidos en las provincias fronterizas de Galicia, Castilla y Extremadura, constituirán uno de los principales quebraderos de cabeza para las autoridades republicanas, temerosas de la reedición de nuevos procesos involutivos. El activismo desarrollado por este colectivo será especialmente relevante en dos áreas por diferentes circunstancias: Galicia y Madrid.

En Galicia, en especial en las provincias de Pontevedra y Orense, era donde se concentraba el grupo más numeroso y activo de los emigrados por su cercanía al septentrión lusitano, bastión del monarquismo, de donde procedían buena parte de los rebeldes que habían participado en las aventuras conspirativas de la Monarquía del Norte y las incursiones gallegas de Paiva Couceiro. Por otra parte, los tradicionales lazos históricos, sociales y económicos existentes entre ambas regiones miñotas hacían del sur galaico la zona preferible para fijar su residencia.

La otra zona a tener en cuenta era Madrid, no por la relevancia cuantitativa de los refugiados sino por ser el lugar de residencia elegido por el directorio que dirigía el exilio monárquico ${ }^{20}$. En este caso las razones para tal elección también eran obvias pues la capital española ofrecía a los líderes del exilio la proximidad a los contactos españoles de más peso con los que podían contar en los círculos de poder de la capital. Desde allí se dirigía al colectivo y se gestionaban los notables recursos monetarios necesarios para mantener una estructura organizativa que analizaremos más adelante.

La organización del exilio en España se realizó baja una estructura claramente jerarquizada, no en vano entre sus dirigentes predominaban ex oficiales del ejército portugués, con sede central en Madrid y compuesto de tres órganos fundamentales: el comando central, un consejo administrativo y un consejo disciplinario ${ }^{21}$. El comando central era el máximo órgano de decisión; el consejo administrativo se encargaba de la gestión de los subsidios dirigidos a los fieles a la causa real que se encontraban sin ningún medio de vida en España tras su huida de Portugal y el consejo disciplinario atendería a las cuestiones propias de su denominación, aplicando la legislación militar vigente hasta el advenimiento de la República, incluyendo en su jurisdicción a los civiles que percibían subsidios de la caja del comando central.

Por último, en un escalón inferior existían comandos militares locales entre los que descollaba el de Vigo del que a su vez dependían el resto de comandos

20 TORRE GÓMEZ, Hipólito de la. Del «Peligro Español» a la Amistad Peninsular. Portugal-España. 1919-1930. Madrid, Editorial UNED, 1984. Págs. 40-41.

21 Ídem, pág. 42. 
del sur gallego (Monforte, Orense, Verín, Tuy...). Vigo era por tanto, el centro neurálgico de las actividades desarrolladas en tierras gallegas por los exiliados, motivo por el cual también contaba con una delegación de la comisión de administración y disciplina dependiente de Madrid. Varias eran las razones que habían hecho de esta ciudad el principal foco de atracción para los monárquicos: su cercanía a Oporto y el norte lusitano, su condición de gran urbe industrial con las comodidades que ello aparejaba, la posibilidad de pasar más desapercibido para evitar las órdenes de internamiento y su papel de gran puerto transoceánico, base de numerosas compañías marítimas que facilitaban una posible emigración a América, en especial a Brasil, alternativa de escape que eligieron no pocos emigrados.

\section{DE LAS REQUISAS AL CONTRABANDO: LAS FUENTES DE FINANCIACIÓN DEL COLECTIVO MONÁRQUICO PORTUGUÉS}

La cohesión organizativa del colectivo exiliado realista en España era posible gracias al dinero que le proporcionaban diversas fuentes de recursos puestas al servicio de la causa. Hemos podido identificar algunas que aparecen en las fuentes primarias consultadas que por la incidencia que se hace sobre ellas podemos considerar que se encuentran entre las más importantes. Eran actividades muy diversas que iban desde las perfectamente legales, pasando por las que bordeaban la legalidad, según el enfoque ideológico que se le quisiera dar al asunto, hasta llegar a las que se encuadrarían en actividades delictivas. A continuación, a través del esquema que sigue, tipificaremos las más reseñables.

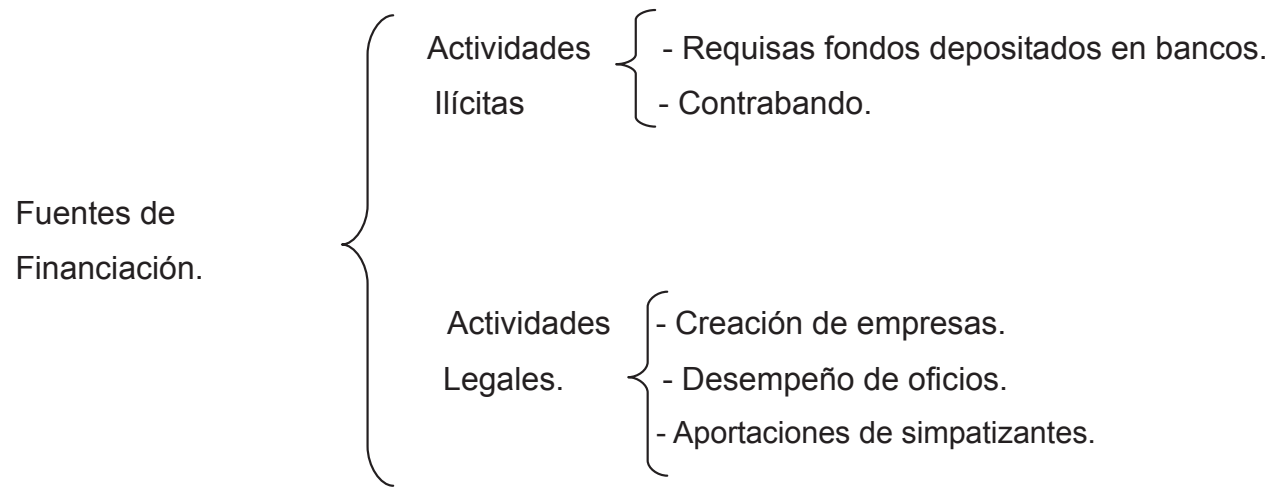

Entre el grupo de las actividades ilícitas que supusieron una fuente de recursos para el colectivo de emigrados, en un primer momento destacaron las requisas de grandes cantidades de dinero efectuadas en entidades bancarias, caso de 
las delegaciones del Banco de Portugal, que realizaron las tropas insurrectas en las localidades que mantuvieron bajo su control durante la Monarquía del Norte. De ello hay referencias en fuentes archivísticas como las registradas en el Arquivo Histórico Militar de Lisboa donde se mencionan las realizadas por los rebeldes realistas en Braga, de cuya Agencia del Banco de Portugal se tiene constancia de haber efectuado repetidas retiradas de dinero o en el Archivo Histórico Nacional de Madrid donde está registrada una comunicación del Gobernador Civil de Zamora que informa de otra requisa realizada en Braganza tras recibir un telegrama del alcalde republicano de la localidad lusa en el que advertía que «una partida de bandoleros en su mayoría paisanos, pocos militares, con varios prisioneros paisanos, entre ellos militares Álvaro Alegre de Vinaes y algunos mandados por el Comandante Varqueipo y Alférez de la Guardia Fiscal Monteiro, debieron pasar la raya esa provincia, entre Alcañices y Bermillo, llevando robadas de la sucursal del Banco en dinero y papeles de crédito particular allí depositado mas de 130.000 duros. Estando las comunicaciones cortadas con Portugal, me veo en la necesidad de poner este telegrama en La Gudiña. Se pide a VS. el arresto y la libertad de los que sean prisioneros. Para el cumplimiento de este servicio he dado las órdenes oportunas a la Guardia Civil de esta provincia»22.

Otra de las actividades al margen de la ley en la que se vieron implicados los contrarrevolucionarios residentes en Galicia lo constituyó el contrabando efectuado en la «raia» (frontera) entre Galicia y el norte de Portugal. La actividad contrabandista, ya habitual en las localidades fronterizas, reportaba unos beneficios lo suficientemente interesantes como para arriesgarse a infringir la ley (algo que ya habían asumido tras ser derrotados en Portugal) por lo que será un atractivo medio de vida para un sector de la emigración realista para lo cual se valdrán de los contactos que tenían tanto en territorio portugués como español para traficar con diversos productos desde ambos lados de la frontera, eludiendo los controles aduaneros. Es así como al lema triádico «Dios, Patria y Rey», en un alarde de malabarismo moral, los contrarrevolucionarios no tenían reparos en asociar el contrabando, convirtiendo la tradicional tríada en tétrada, como actividad generadora de recursos para la causa. Quedaba así bosquejado un apasionante cuadro social en el sur gallego de principios del siglo pasado con la presencia de agentes monárquicos conspiradores asociados al caciquismo y conservadurismo local, fuerzas del orden e incluso «elementos jaimistas» ${ }^{23}$ en los que idealismo e interés crematístico se entrelazaban bajo la sombra del manuelismo.

${ }^{22}$ ARCHIVO HISTÓRICO NACIONAL, Madrid (AHN). Fondo del Ministerio de Gobernación. «Portugal 1919» LEGAJO 48-A n.ㅇ 9. Telegrama oficial $n .-919$ (15 de febrero de 1919) (Expediente n.으. 20). Gobernador Civil Zamora a Ministro de la Gobernación.

${ }^{23}$ AHN. Fondo del Ministerio de Gobernación. «Portugal 1919» LEGAJO 48-A n.ำ 9. Telegrama oficial n.. 1269 (29 de mayo de 1919) (Expediente n.ำ).Ministro de la Gobernación a los Gobernadores Civiles de Coruña, Orense, Pontevedra y Zamora.

Los jaimistas eran los seguidores del pretendiente carlista D. Jaime, quien había designado para desempeñar la secretaría política del movimiento carlista a Vázquez de Mella que por su germanofilia terminó siendo desautorizado por el pretendiente. 
Existen numerosos testimonios de este tráfico ilícito, que salpicaba con sus corruptelas la reputación de empleados públicos de ambos países e incluso, por los notables lucros que podían representar, a insignes personajes de la sociedad gallega. A finales de 1919 el diario español «El País» publicaba las impresiones obtenidas por el diputado republicano riojano Eduardo Barriobero ${ }^{24}$ tras su visita a tierras gallegas, invitado por la Federación de las Izquierdas de Orense, adonde se había trasladado para «comprobar por sí mismo los escandalosos manejos de los monárquicos portugueses, estacionados a lo largo de toda la línea fronteriza en la región galaica» ${ }^{25}$. Barriobero, después de recorrer diferentes localidades del sur de Galicia (Verín, Orense, Vigo, Pontevedra, Tuy), pudo comprobar en persona cómo «es indudable que reaccionarios y paivantes hacen allí casi siempre lo que les viene en gana, porque en Galicia no manda el gobierno de Madrid ni las autoridades de allí, sino el "virrey Riestra"»26.

¿Cuáles eran los intereses, denunciados en artículos como este por la prensa republicana española, del caciquismo local gallego para apoyar a los monárquicos lusos refugiados? ¿Se trataba de un gesto de solidaridad fraguado en una comunión ideológica bajo el frontispicio común de «Dios, Patria, Rey»? No, o al menos no solamente por motivos ideológicos, pues también parecía haber razones más mundanas que apuntaban a los jugosos réditos que reportaba la colaboración con los correligionarios vecinos ¿De qué se trataba?

Barriobero apunta unos argumentos que nos inducen a pensar en que pueden ser tenidos por verosímiles si se contrastan con la información que proporcionan las fuentes archivísticas. El político republicano riojano afirmaba que «la protección que se les dispensa a los realistas lusitanos es bastante interesada pues se comercia con ellos, vendiéndoles armas y procurando contrabandear con Portugal productos alimenticios». ${ }^{27}$ El comercio ilegal en la frontera del Miño, «a raia» miñota, había sido (y seguirá siendo mientras exista dicha frontera hasta bien entrado el siglo XX) un apetitoso negocio para las redes contrabandistas que operaban en ambas márgenes por lo que, si en 1919 se le añadía un nuevo elemento como era la existencia de una nutrida colonia de portugueses en ese territorio, deseosos de sacar provecho de este tráfico ilegal a través del contrabando de productos alimenticios y de armas, por su propio interés y por el de la Restauración, obtendremos una hipótesis bastante verosímil de por qué podrían existir ra-

\footnotetext{
${ }^{24}$ Eduardo Barriobero, reconocido abogado y político republicano riojano próximo al anarconsindicalismo, forjó su prestigio como defensor legal de los obreros durante la Monarquía alfonsina y la II República. Tras la caída de Barcelona en la Guerra Civil, fue fusilado por las tropas franquistas por su responsabilidad en la organización de los tribunales populares y de justicia revolucionaria en la ciudad condal.

25 «El País». «Galicia vivero de conspiradores portugueses», 17 de noviembre de 1919, Madrid.

26 José María Riestra y López, marqués de Riestra, fue uno de los más conspicuos caciques gallegos en la España de la Restauración que, a la sazón, controlaba los resortes electorales de la provincia de Pontevedra. Para más información léase «El poder de la influencia: geografía del caciquismo en España (1875-1923)» de José Varela Ortega, Carlos Dardé, Josep Armengol i Segú y otros, Marcial Pons, 2001.

27 «El País». «Galicia vivero de conspiradores portugueses», 17 de noviembre de 1919, Madrid.
} 
zones de peso que justificasen la permisividad de una parte de las autoridades locales gallegas al punto de denunciarse hechos como que «se da el caso, el escandaloso caso, que al gobernador de Pontevedra que quiso algo en cumplimiento de la ley y envió treinta guardias civiles con rigurosas órdenes contra los conspiradores portugueses, ni en Tuy ni en Vigo, le obedecieron pues, según dicen ellos, allí son "los amos"»28.

En efecto, Barriobero no tiene reparos en apuntar a los que considera principales responsables de esta red de personajes principales que protegían al colectivo de exiliados. En este entramado descollaban destacadas figuras públicas como el gobernador civil de Orense «el cual francamente defiende a los agitadores portugueses. Este señor es un boticario de Porriño, cacique de dicho pueblo. Y ocurre que los días de mercado el buen boticario de Porriño deja el Gobierno Civil de Orense y se va a despachar recetas, abandonando cuanto conflictos tenga como autoridad civil y así ha ocurrido recientemente con una huelga de tipógrafos». ${ }^{29}$ También alcaldes, como el de Verín «que no celebra sesiones en su concejo, en cambio consiente escenas de chulapería y provocación de los portugueses. Los conspiradores hacen allí lo que les viene en gana. Se meten con los republicanos de su país y con los del nuestro y hacen ejercicios militares a la vista del todo el mundo, jactándose de decir que en cuanto puedan volverán a intentar la restauración de la monarquía de los Braganza»30.

Pero es en Vigo, la principal urbe del sur gallego, donde se encuentra la plana mayor del exilio monárquico luso que desde la ciudad olívica dirige las diferentes actividades asociadas a la discreta red logística que los refugiados habían desarrollado; hasta el extremo que «en Vigo funciona un verdadero Estado Mayor que prepara y dirige todos los movimientos y da las órdenes de propaganda. Pero el elemento que allí bulle es más prudente que los exaltados "trauliteros" 31 de Verín».

También Redondela, localidad próxima a Vigo, contaba con una significativa presencia de mujeres realistas según las informaciones reportadas por Barriobero que no escapan a cierto tono anticlerical y machista. Se trataba de un «ejército femenino de las entusiastas partidarias del desdichado ex rey Manolito. Los frailes tienden sobre ellas su generosa tutela, y con la hábil perfidia de que son capaces, las utilizan como discretas transmisoras de encargos, de secretos y de

28 Ídem.

29 ĺdem.

30 Ídem.

31 Los contrarrevolucionarios monárquicos eran conocidos por los republicanos con el despectivo término de «trauliteiros» que equilvadría a «mamporreros» pues traulito en portugués significa «porra, palo». Por tanto la alusión sería a la mala fama que tenían entre los republicanos los elementos realistas más exaltados que recurrían a la violencia para imponer sus criterios. Por esta razón también a la «Monarquía del Norte» se la denominaba «O Reino da Traulitania». 
órdenes delicadas. Téngase en cuenta que estas distinguidas damas lusitanas son ricas en su mayoría, y dense por adivinadas muchas cosas» 32.

Este tipo de noticias publicadas en la prensa española tenía su difusión en Portugal de modo inmediato, como sucedió con la información del artículo de «El País» a la que se ha hecho referencia,que fue publicada por «O Mundo» ${ }^{33}$ con el consiguiente revuelo en la opinión pública portuguesa, revuelo que se trasladaba al gobierno que acababa manifestando su malestar al representante diplomático español, Alejandro Padilla, que de inmediato solicitaba al Ministerio de Estado que «si algún diario español contesta a El País se sirva avisármelo porque tengo medios para hacer reproducir aquí la respuesta». Se trataba de puntualizar y rebajar el grado de tensión generado por este tipo de artículos entre ambos países, cuestión que dificultaba las tareas diplomáticas de Padilla que advertía a su gobierno que no convenía «que aquí (en Portugal) se crea lo que aquel supone respecto a los manejos de los monárquicos portugueses en España»34. Una labor que se antojaba difícil de cumplir pues no dejaban de salir a la luz los intereses existentes que justificaban el apoyo dispensado en territorio español a la activa colonia de emigrados realistas portugueses.

Poco se podía hacer para dar efectivo cumplimiento al R.D. de 12 de marzo de 1917 que con tanta obstinación solicitaba el gobierno de Lisboa a Madrid ante los beneficios que generaban los turbios negocios entre España y Portugal, como sucedía en el caso del «descarado contrabando de armas que por esta parte de la frontera se está realizando». ${ }^{35}$ Un tráfico ilegal del que ya hacía tiempo se tenía constancia pero que el lucro generado había hecho cubrir con un manto de silencio, un silencio remunerado, claro está, como ya venía siendo habitual en las relaciones fronterizas gallego-portuguesas, donde el contrabando suponía un medio de vida más para un sector de la sociedad agraria de ambas márgenes del Miño. Pero que incluso podía alcanzar localidades más lejanas de la frontera como La Coruña desde cuyo puerto se decía que «han salido varias expediciones de contrabando de armas» 36 .

El otro gran grupo de fuentes generadoras de recursos del colectivo de emigrados lo constituían actividades que, al menos en apariencia, contaban con todas la bendiciones legales y parecían no despertar ninguna sospecha. Se trataba de diferentes sociedades, creadas por miembros destacados del exilio monárquico para el desarrollo de diversos negocios, entre los que se encontraban empresas de gran proyección, que merecían un seguimiento especial por parte de las auto-

\footnotetext{
32 «El País». «Galicia vivero de conspiradores portugueses», 17 de noviembre de 1919, Madrid.

33 «O Mundo» era el órgano de expresión oficial del PRP.

34 ARCHIVO MINISTERIO DE ASUNTOS EXTERIORES, Madrid (AMAAEE), H-2643. Despacho n. $\circ 564.18$ de noviembre de 1919. Ministro de España en Lisboa a Ministro de Estado.

35 AMAAEE, H-2643. Despacho n. 623. 15 de diciembre de 1919. Recorte de prensa del diario «La República» de Pontevedra, 1919 Ministro de España en Lisboa a Ministro de Estado.

36 Ídem.
} 
ridades de Lisboa que daban instrucciones a su cuerpo diplomático para que investigase estas entidades pues no dejaban de ser una fuente de recursos puesta al servicio de la causa monárquica.

Tal es el caso de la "Sociedad Comercial Hispano Portuguesa» en cuya actividad empresarial investigada, y no por casualidad, existía una íntima conexión de las dos principales ciudades en que operaba el exilio monárquico: Vigo y Madrid. Se trataba de una sociedad constituida en Madrid el 9 de abril de 1919 por Ruy Gonçalves Zarco da Cámara, presidente del consejo de admón. y tesorero, Francisco Dantas, Jose de Avellar, José María Eça de Queiroz y Augusto Nogueira Magalhães. La copia de la escritura fue enviada por el cónsul de Portugal en Vigo el 12 de junio de 1919 a Manuel Couceiro da Costa, embajador de Portugal en Madrid $^{37}$. El objeto social de esta compañía era la actividad comercial y contaba con un capital social de 250.000 pesetas de los que se habían desembolsado 100.000 pesetas (una fuerte suma para la época).

Todos los miembros del consejo de administración de la Sociedad Comercial Hispano-Portuguesa pertenecían a un selecto grupo de emigrados monárquicos residentes en Madrid. Ruy Cámara se hospedaba en el Palace Hotel de Madrid, Francisco Dantas en el Grand Hotel (ambos tienen cédula de inscripción de extranjero expedidas en marzo y febrero respectivamente); Avellar tenía su residencia en el número 6 de la calle Goya y se inscribió el 8 de abril; José Eça, hijo del célebre escritor del mismo nombre, hospedado en el Grand Hotel con cédula de inscripción expedida el 8 de abril, que además era apoderado del comerciante de Oporto, Augusto Nogueira de Magalhães, en virtud de un poder otorgado en Vigo $^{38}$.

A pesar de las investigaciones a que se vio sometida, la compañía parecía no tener impedimentos para realizar sus actividades basadas en la intermediación para la importación y exportación de productos entre Portugal y España, pues el 14 de agosto de 1919 envía un escrito a las autoridades españolas solicitando autorización para la realización de una importante operación comercial incidiendo «en el hecho del gobierno portugués haber permitido últimamente y en gran escala la exportación de maderas y otros artículos que han sido vendidas a varias sociedades españolas». Por esta razón la sociedad pretendía negociar con los recursos forestales lusos para «proveer grandes partidas de madera para minas a las sociedades Peñarroya, Hullera Española y Duro Felguera».

La operación descrita sólo podría llegar a buen término si a cambio el gobierno español le otorgaba a la Sociedad Hispano-Portuguesa «la debida autorización para exportar de 10 a 15.000 toneladas de arroz español como compensación al intercambio comercial, pues es justo que el mercado portugués sea beneficiado

${ }^{37}$ ARQUIVO HISTÓRICO DIPLOMÁTICO MINISTÉRIO ASSUNTOS ESTRANGEIROS (AHDMAE). Legação de Portugal em Madrid. Caixa 143. Maço 5.

${ }_{38}$ AHDMAE. Legação de Portugal em Madrid. Caixa 143. Maço 5. 
con esta mercancía que tanta falta le hace y que de ninguna manera perjudica al mercado español». ${ }^{39}$ Se trataba de grandes operaciones de comercio exterior que reportarían un notable beneficio en las que los monárquicos se beneficiaban de los contactos al más alto nivel empresarial que tendrían en ambos países, operaciones que aprovechaban la buena marcha de la actividad económica española gracias a su papel de proveedor de productos a los países en conflicto durante la Primera Guerra Mundial y a las necesidades imperiosas de importar alimentos que vivía Portugal en aquellos momentos y que estaba dando lugar a importantes desórdenes sociales en la primavera y verano de 1919.

Otra muestra de los pingües beneficios que generaban las operaciones comerciales entre Portugal y España, impulsadas por destacados miembros del exilio realista portugués lo tenemos en las circunstancias que rodearon al asesinato del auxiliar del cónsul de Portugal en Verín, que trataremos con detalle más adelante. Cuando se remite la información del luctuoso hecho al Diario de Orense por el corresponsal de la villa, el boticario republicano Plácido Amoeiro, para sorpresa de sus compañeros republicanos, Amoeiro «telegrafía primero infamias al Diario de Orense, y envía correspondencias después que son indignas de su pasado», distorsionando la información del asesinato hasta el punto de favorecer la suerte del asesino y de sus cómplices lo que produce una mezcla de indignación y sorpresa en sus correligionarios que intentan desentrañar el trasfondo de este cambio de actitud.

Pronto son desenmascarados los intereses del boticario, al que hasta entonces tenían por un republicano de intachable honradez muy apreciado por la sociedad verinense, que habían provocado su cambio de actitud. Plácido Amoeiro «así como otros varios capitalistas de Verín, estaban comprometidos en negocios cuyos intermediarios eran los emigrados portugueses; que se habían realizado algunos por valor de 50.000 duros y que había quien en un sólo día se había tragado 14.000 pesetas» 40 .

Las informaciones sobre los turbios negocios de Amoeiro son confirmadas por el diario «La República» donde llegan al convencimiento de que el informador no les engañaba al comprobar que «en últimos de agosto o primeros de septiembre, se había facturado en la estación del ferrocarril de Orense para Barcelona una gran partida de anilinas ${ }^{41}$ procedente de Portugal, valorada en más de 50.000 duros y de la que tal vez el corresponsal del Diario de Verín (Plácido Amoeiro) pudiera dar más datos. El día 10 del corriente también se facturó otra partida de lo mismo y de la misma procedencia de 927.500 kilos cuyo importe es de la misma cantidad en pesetas. 100.000 duros que juegan en este importante negocio,

39 Ídem.

40 AMAAEE, H-2643. Despacho n. 623. 15 de diciembre de 1919. Recorte de prensa del diario «La República» de Pontevedra, 1919. Ministro de España en Lisboa a Ministro de Estado.

41 Amina aromática, oleosa e incolora que tiene muchas aplicaciones industriales, especialmente en la fabricación de colorantes. 
dan margen más que suficiente para sostener contra todo derecho y razón la defensa de quien los negocia, aún a trueque de amistad, la justicia y las ideas». ${ }^{42}$

Las razones económicas por tanto eran fundamentales para que se conformase un entramado de intereses entre emigrados portugueses, autoridades civiles españolas e incluso, como en el caso del boticario Plácido Amoeiro, para comprar voluntades de hasta entonces intachable trayectoria republicana.

Había otras alternativas para financiarse, desde las más habituales, como era desempeñar trabajos más o menos cualificados, dependiendo de la situación de cada emigrado, como sucedía con Manuel Carpinteiro, un oficial de caballería refugiado en Badajoz, que tras comprar una máquina trilladora se dedicaba a realizar trabajos agrícolas. O bien, recibir remesas de dinero de organizaciones afines como sucedía con la liga monárquica portuguesa de Río de Janeiro que ya en el pasado había dado un importante soporte financiero a los movimientos contrarrevolucionarios tras la implantación de la República ${ }^{43}$.

\section{EL ACTIVISMO CONTRARREVOLUCIONARIO DE LOS EMIGRADOS REALISTAS EN ESPAÑA: UN ELEMENTO DISTORSIONADOR EN LAS RELACIONES ENTRE PORTUGAL Y ESPAÑA}

Ya en pleno movimiento sedicioso de la Monarquía del Norte, así como al poco de ser sofocado, los servicios de información, bajo la dirección del Ministerio de Guerra republicano luso, centraban su atención y recursos (puestos fronterizos, consulados, colaboradores republicanos españoles,...) en tratar de controlar los movimientos del exilio monárquico en España ante la amenaza que suponía la organización de nuevos levantamientos. Los informadores realizaron un exhaustivo seguimiento de los exiliados portugueses, en especial en tierras gallegas, pues era la zona «caliente» desde la que se podía esperar una nueva incursión armada en territorio portugués, emitiendo numerosos informes (con mayor o menor precisión) al Ministerio de Guerra de la actividad desplegada por los emigrados.

¿Por qué esa insistencia de los exiliados portugueses en el incumplimiento de las órdenes de internamiento que los alejasen de las localidades fronterizas? Según la versión del gobierno portugués estas maniobras respondían a que «la cuestión vital para su objetivo político es afianzar su residencia cerca de la frontera portuguesa y, para conseguir ese fin, usan todas las estratagemas, sirviéndose de las influencias locales que siempre los protegen, para eludir las órdenes emanadas de los gobernadores civiles de su Majestad». ${ }^{44}$ Para solventar este

42 AMAAEE, H-2643. Despacho n. 623. 15 de diciembre de 1919. Recorte de prensa del diario «La República» de Pontevedra, 1919. Ministro de España en Lisboa a Ministro de Estado.

43 TORRE GÓMEZ, Hipólito de la. Op. cit. en nota (6). Pág. 41.

44 AMAAEE, H-2643. Despacho n.ํ 96. 30 de abril de 1919 Ministro de Portugal en Madrid a Ministerio de Estado. 
problema, el ministerio de exteriores luso propuso al gobierno español «la prohibición de residencia en todos los territorios de las provincias españolas que hacen frontera con Portugal, a todos los portugueses que no puedan legalmente, con el respectivo pasaporte expedido por las autoridades competentes de la República, justificar su estadía en España» 45.

La petición portuguesa es rápidamente aceptada por Madrid que dicta orden al Ministro de Gobernación para que envíe instrucciones a los gobernadores civiles de las provincias fronterizas «reiterándoles la necesidad absoluta de impedir la residencia en ella de portugués alguno emigrado» 46 . Y de ello informaba puntualmente el ministro de Estado Hontoria al ministro de Portugal en Madrid, Manuel Couceiro da Costa, al que aseguraba que «se han dado órdenes terminantes y repetidas a los jefes de la Guardia Civil y a los alcaldes de los pueblos fronterizos a Portugal, para bajo su más estrecha responsabilidad, den cuenta diaria de la entrada y permanencia de emigrados políticos portugueses, insistiendo en la orden de internación y dando cuenta al Ministerio de la Gobernación de cada caso que se presente».

Parece claro que desde las altas instancias del gobierno español había buena disposición para satisfacer las demandas del gobierno republicano portugués, que exigía que se mantuviese controlado al numeroso grupo de realistas portugueses residentes en suelo español y evitar así una posible tentativa golpista dirigida desde España, sin embargo otra cosa parecía ser que las órdenes dadas a las autoridades locales fueran aceptadas y cumplidas con el rigor deseado.

La libertad de movimientos de la que gozaban los emigrados les habría permitido tejer una red de contactos y apoyo a su colectivo, como ya se ha comentado, que tenía su centro de mando en Madrid. La infraestructura organizativa era financiada a través de los fondos depositados en bancos españoles con los que se hacía frente a los gastos que el colectivo exiliado originaba como era advertido por el Ministerio de la Gobernación que aseguraba que «los monárquicos portugueses refugiados en España trabajan en contra del Gobierno portugués constituido, recibiendo dinero, especialmente del Banco de Bilbao. Se añade que de Galicia vienen a Madrid con frecuencia algunos monárquicos portugueses para recibir instrucciones, y que de La Coruña y de otros puntos han salido expediciones de contrabando de armas, que es apoyado por los elementos jaimistas, teniendo puestas las miras para entrar en Portugal por Braganza, y existiendo en varios puntos de la frontera depósitos de armas, señalándose las provincias de Orense, Zamora y en Bande, Trimo y Pontevedra, como puntos principales de la conspiración. Encarezco a V.S. absoluta necesidad de que se cumplan instrucciones reiteradísimas de este Ministerio, de alejar de las provincias fronterizas a todo mo-

\footnotetext{
45 AMAAEE, H-2643. 3 de junio de 1919 Ministro de España en Lisboa a Ministro de Estado.

46 AMAAEE, H-2643. Telegrama cifrado, 6 de junio de 1919 Ministerio de la Guerra a Ministerio de Estado.
} 
nárquico portugués y de que se ejerza estrecha vigilancia para impedir toda clase de movimientos políticos contra la tranquilidad de la vecina República, esperando que V.S. me dará la seguridad de que se cumplen aquellas y de que por esa provincia no hay temor alguno de tentativas de ninguna clase» ${ }^{47}$.

Las muestras de disgusto, expresadas por representantes del gobierno de Lisboa al embajador Padilla, a causa de la información recibida de los numerosos incidentes protagonizados por los contrarrevolucionarios emigrados, son recurrentes por lo que este se ve en la obligación de dar cumplida información a Madrid. El 20 de febrero el diplomático transmite, a través de telegrama cifrado, el malestar del Director General de Negocios Extranjeros ante las provocaciones y hechos violentos causados en España por exiliados monárquicos a representantes de la República de Portugal, siendo la más significativa una manifestación realizada ante el consulado portugués en Tuy en la que se profirieron gritos insultantes contra el gobierno republicano y contra un grupo de militares lusitanos que se encontraba de visita en la localidad pontevedresa, incidentes que finalizaron con el apedreamiento de la legación lusa. Dichos actos como recalcaba el gobierno portugués «eran perjudiciales para los dos países, enconando los ánimos» ${ }^{48}$.

Lo acontecido en Tuy (recordemos que hacía tan sólo unos días que Oporto había caído en manos republicanas) había sido posible porque los exiliados implicados en los hechos no habían cumplido las órdenes de internamiento, al serles concedido un plazo de 3 días para reunir el dinero necesario para pagarse su traslado al interior de Galicia, y en ese lapso de tiempo se habían producido los altercados. Por su parte el Gobernador Civil trataba de enmendar la plana, no sería la última vez, asegurando que había tomado las medidas necesarias para "que inmediatamente por la Alcaldía y Jefe de Línea de la Guardia Civil (de Tuy) se expulse como tenía ordenado, siguiendo las instrucciones de V.E. a dichos emigrantes para la provincia española no fronteriza y si careciesen de medios, que la conducción se verifique en la forma y con los recursos ordinarios» 49.

Finalmente los emigrados implicados en la trifulca fueron llevados a Guillarey y de allí partieron en ferrocarril con dirección a Monforte de Lemos (en el sur de Lugo) el 18 de febrero, 24 horas después de los sucesos de Tuy, lo que demuestra la buena voluntad española para satisfacer las demandas de Lisboa para atajar este tipo de actos.

Días más tarde el comandante militar de Valença, teniente coronel Augusto María Soares, envía un informe al jefe de Estado Mayor de la 8. ㄹ División, Hen-

\footnotetext{
47 AHN. Fondo del Ministerio de Gobernación. «Portugal 1919» LEGAJO 48-A n.ำ 9. Telegrama oficial n.. 1269 (29 de mayo 1919) (Expediente n.․ 1).Ministro de la Gobernación a los Gobernadores Civiles de Coruña, Orense, Pontevedra y Zamora.

${ }_{48}$ AMAAEE, H-2643. Telegrama cifrado n.. 103.20 de febrero de 1919 Ministro de España en Lisboa a Ministro de Estado.

${ }^{49}$ AMAAEE, H-2643. Telegrama n.ํ 1102. 22 de febrero de 1919 Gobernador Civil a Ministerio de Guerra.
} 
rique Pires Monteiro, en el que denuncia entre otras cosas que los exiliados campan a sus anchas en suelo gallego donde han adquirido material de guerra y cuentan con la colaboración de los jaimistas, lo que pone en evidencia la posible colaboración del legitimismo español con el exilio realista portugués. Dicha conexión queda registrada en la queja del embajador portugués en Madrid, Teixeira Gomes, al subsecretario de estado español en la que le ponía al corriente de una operación de compra de armas que, «por intervención del Sr. Vázquez de Mella ${ }^{50}$ y otras personas influyentes», el tesorero de los exiliados, Augusto de Aguiar, había cerrado en Madrid la adquisición de «8.000 mausers y 12 millones de cartuchos para ser entregados a los conspiradores en el plazo de cuarenta días» 51 .

El plan para introducir esta partida de armas en territorio portugués consistiría en «meterlas en toneles que sirven para aceite y transportarlas en carromatos»; mientras no se efectuara el traslado el depósito del armamento quedaría en la casa «Viuda y Hijos de Rafael González» en la calle Reina en Lugo ${ }^{52}$. Fuera errada o no esta información, no era en absoluto descabellada ya que en octubre de 1919 cerca de la frontera portuguesa en la provincia de Salamanca se descubrió un gran depósito de armas y municiones con una enseña realista portuguesa lo que no parecía dejar ninguna duda de la existencia de la voluntad por parte de los contrarrevolucionarios de organizar nuevas partidas armadas desde España ${ }^{53}$.

Con el goteo incesante de emigrados que conseguían cruzar la frontera y alcanzar suelo español comenzaron a menudear las alteraciones de orden público. No se trataba sólo de meros actos de desobediencia a las órdenes de internamiento dictadas por el gobierno de Madrid, sino también de la aparición de frecuentes incidentes causados por los miembros más hostiles de la hueste azul y blanca residente en territorio español España hacia sus paisanos republicanos, que residían también en España o simplemente se encontraban de visita.

Los actos de agravio eran de muy variada índole y gravedad, podían ser meras bravuconadas como la acaecida el 21 de abril de 1919 en la población fronteriza lusa de Segadães cuando se procedía «al lanzamiento solemne de una red y a las bendiciones de las aguas del río Miño, mis compatriotas que asistían a la ceremonia fueron provocados e insultados por emigrados que se encontraban en la otra margen, llegando incluso algunos a pasear en barco por el río enarbolan-

\footnotetext{
50 Vázquez de Mella fue un reputado político tradicionalista español quien en aquellas fechas lideraba el Partido Católico Tradicionalista, fundado por él mismo, al romper sus vínculos con el carlismo a causa de las críticas recibidas por el pretendiente D. Jaime a aquellos legitimistas que, como sucedió con Vázquez Mella, habían mostrado tendencias germanófilas durante la Gran Guerra.

51 AMAAEE, H-2643. marzo de 1919 Ministro de Portugal en Madrid a Ministro de Estado.

52 Ídem.

53 DE LA TORRE, Hipólito. Op. cit. en nota 10. pág. 41.
} 
do la bandera del extinto régimen ${ }^{54}$. Pero de la violencia verbal y gestual se llegaba en muchas ocasiones a la violencia física, llegando a agredir a todo ciudadano portugués que defendiese o representase los intereses de la República, como sucedió en septiembre de 1919 cuando el Ministerio de Estado español transmitía al Gobierno Civil las quejas recibidas del cuerpo diplomático luso en Madrid que denunciaba que «los conspiradores portugueses residentes en Vigo continúan ejerciendo actos de provocación, habiendo agredido el día 25 de septiembre un grupo de aquellos por sorpresa al Secretario de Administración del Concejo de Monção y a un funcionario del Consulado de Portugal. Reitero a V.S. órdenes terminantes comunicadas por este Ministerio para que se proceda a la internación de dichos emigrados portugueses, y espero que hará cumplir la orden sin demora alguna, dándome cuenta» ${ }^{55}$.

Pocos días después, el 6 de octubre de 1919, el jefe del puesto fronterizo de Valença, capitán Custódio António Marques, vuelve a remitir un nuevo informe en el que pone en conocimiento de la Secretaría del Ministerio de Guerra las amenazas y actos violentos que en Vigo han recibido republicanos portugueses por parte de exiliados monárquicos. Es el caso de las amenazas e insultos proferidos por monárquicos entre los que sobresalía Álvaro Rebello Valente, padre del teniente Valente que había sido ayudante de Paiva Couceiro, contra 3 republicanos que se alojaban en un hotel de la ciudad olívica el 4 de octubre.

Aprovecha Marques para comunicar que en cuanto el Sr. Álvaro Rebello Valente regrese a Oporto será remitido al comisario de policía para retirarle el pasaporte, pues al parecer se vale de sus viajes a Vigo para conspirar en España contra la República. Finaliza su informe, insistiendo en el peligro de involución monárquica y en la llegada a Tuy de diversos exiliados para conferenciar con los que allí residen así como del dinero que siguen percibiendo, según su categoría, para subsistir en tierras españolas ${ }^{56}$, cabe señalar que en este caso es remitida una copia de la información al Ministerio de Exteriores.

Dentro de esta larga cadena de agresiones causadas por los refugiados monárquicos, el incidente que alcanzó mayor gravedad tuvo lugar en Verín el 16 de noviembre cuando, en una acalorada discusión, un emigrado monárquico descargó un revólver contra un funcionario del Consulado portugués de la villa orensana. Los hechos, relatados por el propio alcalde de Verín al Gobernador Civil de Orense, tuvieron lugar a las ocho de la noche cuando «el súbdito portugués Sergio Correa disparó en la calle Mayor (de) aquella villa a otro portugués de

\footnotetext{
${ }^{54}$ AMAAEE, H-2643. Despacho N.9 96. 30 de abril de 1919. Ministro de Portugal en Madrid a Ministro de Estado.

${ }_{55}$ AHN. Fondo del Ministerio de Gobernación. «Portugal 1919»LEGAJO 48-A n.ㅇ 9. Telegrama oficial n.․․ 235 (4 de octubre de 1919) (Expediente N․ํ 15).Ministro de la Gobernación a Gobernador Civil Pontevedra.

${ }^{56}$ AHM. Capitán Custódio António Marques, comandante del puesto fronterizo de Valença (6-10-1919). Lisboa, 1.ํㅡㄹivisão, 37 Seccão, Caixa 51, Maço 2.
} 
nombre Manuel Moure, varios tiros que le dejaron gravemente herido y que según sus informes fallecerá en breve. Fue debida agresión a discusión acerca del estado Portugal. Agresor se fugó sin poder capturarle por falta Guardia Civil»>57. Era la gota que colmaba el vaso de una situación caldeada por puntuales encontronazos en la pequeña villa orensana; situación que ya había sido denunciada por el propio alcalde y el Cónsul de Portugal «que manifiestan que son objeto de amenazas constantes por parte de varios portugueses. Para garantizar el orden y la seguridad dichas personas, esta mañana he trasladado telegrama referencia al Teniente Coronel Guardia Civil a fin de que la fuerza eventualmente se encuentra en Verín continúe por algún tiempo aquella villa hasta que vuelva a la tranquilidad»s 58 .

Lisboa pretendía que el gobierno de Madrid no bajase la guardia y continuase con la colaboración a la que se había comprometido para controlar las actividades del exilio realista. De hecho, el gobierno republicano portugués había expresado desde un primer momento su agradecimiento a su homólogo español al conocer «las severas instrucciones dadas por el señor presidente del Consejo, mi querido amigo, señor conde de Romanones, para que sean internados los revolucionarios monárquicos que se encuentran en la frontera»59. Por lo tanto, la República lusa aguardaba con esperanza que la orden de internamiento evitase reeditar el enturbiamiento de relaciones entre los dos países ibéricos al «evitar todo pretexto para las intrigas de los conspiradores, semejantes a las que efectuaron en 1912» a la vez que manifestaba para la consecución de tal fin confiar «absolutamente en el Excmo. Señor Conde de Romanones y en V. Ex. ${ }^{{ }^{3},{ }^{6}}{ }^{60}$

A mediados de marzo el embajador portugués en Madrid comunicaba que, según sus informaciones, sólo en Vigo se encontraban «cerca de 800 emigrados revoltosos. En los hoteles Continental, Francia y Universal ${ }^{61}$, sobre todo en este último, están instalados 50 emigrados y entre ellos el conocido agitador Domingos Pereira ${ }^{62}$, así como gran parte de la oficialidad revoltosa del Regimiento de Caballería $n .^{\circ} 9_{>}{ }^{63}$. Pero el Hotel Universal no era simplemente un lujoso alojamiento que albergaba a lo más granado del exilio monárquico en Galicia, también

57 AHN. Fondo del Ministerio de Gobernación. «Portugal 1919» LEGAJO 48-A n.ำ 9. Telegrama ofi-

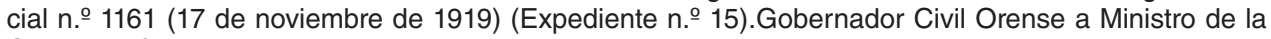
Gobernación.

58 AHN. Fondo del Ministerio de Gobernación. «Portugal 1919» LEGAJO 48-A n.ำ 9. Telegrama ofi-

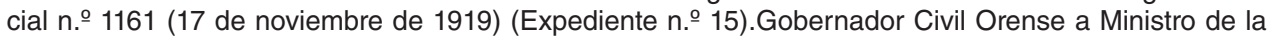
Gobernación.

59 AMAAEE, H-2643. Carta de José Relvas, presidente del gobierno portugués, al embajador Alejandro Padilla, 7 de marzo de 1919.

60 Ídem.

61 El Hotel Universal, obra eclecticista diseñada por Jenaro de la Fuente, está hoy todavía en uso después de una reforma que respetó su fachada y estructura original. El Universal era uno de los hoteles más señeros de la ciudad donde en su restaurante y terraza se reunía lo más granado de la burguesía viguesa a la que se sumaban los distinguidos huéspedes del hotel.

62 El padre Domingos era un destacado miembro del directorio monárquico exiliado en Galicia.

63 AMAAEE, H-2643. 15 marzo de 1919 Ministro Portugal en Madrid a Ministro de Estado. 
tenía una función que preocupaba al gobierno republicano pues en sus dependencias «celebran los revoltosos portugueses reuniones que acostumbran a ser muy concurridas» 64 , lo que le hacía uno de los puntos de encuentro predilectos del comando militar de Vigo. Además de Vigo, los emigrados monárquicos también se habían instalado en Tuy, Guillarey, Redondela y otras poblaciones cercanas a la frontera «adonde los emigrados concentrados en Vigo hacen constantes viajes».

Tal cantidad de emigrados y la facilidad que tenían para cruzar la frontera desde Galicia hacían que con frecuencia saltasen las alarmas en Lisboa. El clima de psicosis era tal que en el agitado verano de 1919,que sacudía a Portugal con numerosas huelgas, se esperaba que la situación fuera aprovechada por la contrarrevolución monárquica afincada en España para realizar una operación desestabilizadora de gran calado que incluía el asesinato de destacados miembros de la República. M. Godinho da Cruz, cónsul de Portugal en Tuy, daba cuenta a sus superiores del Ministerio de Exteriores en Lisboa que por el momento no había encontrado pistas que le hiciesen «saber si ya entraron en Portugal los individuos, escogidos por el comité de la conspiración de Madrid, encargados de asesinar, en el momento oportuno a los excelentísimos señores Presidente del Ministerio y Ministro de Guerra Dr. António José d'Almeida y Machado dos Santos» 65.

Godinho alertaba que para evitar tal situación de riesgo era necesario hacer menos permeable el paso de ciudadanos españoles a Portugal, para ello recomendaba que «no se debía permitir la entrada en el país a españoles sólo con la cédula personal y mediante la declaración que vienen para tomar las aguas y es que, a la sombra de esta regalía, entra toda la gente en el país sin otros documentos» ${ }^{66}$. El problema que el cónsul veía en la facilidad de permitir el paso de la frontera a los españoles tan sólo con la presentación de su tarjeta de identificación era que «la llamada cédula personal no es documento privativo, como debería ser de españoles: cualquier portugués puede conseguir idéntico papel, y casi todos los residentes aquí son sus poseedores, porque a los cobradores de impuestos que las expiden no les importa la calidad o nacionalidad de los solicitantes, mirando tan solo las pesetas».

Era pues la facilidad que daban algunos funcionarios españoles para conseguir dicho documento, lo que hacía arriesgado mantener un control efectivo sobre las verdaderas intenciones de las personas que viniendo de España llegaban a Portugal, siendo aprovechada la oportunidad por los emigrados. Tan seguro Godinho estaba de la laxitud española en la expedición de las cédulas personales que se atrevía a asegurar a su superior que «en caso de duda en el espíritu de su

64 Ídem.

65 AHDMAE. Legação de Portugal em Madrid. Caixa 143. Maço 5. Despacho confidencial n.ํㅜ 67/919. Del Consulado de Portugal en Tuy para el agregado militar de la embajada de Portugal en Madrid, 27 de junio de 1919.

66 ídem. 
Exca., al respecto de lo que afirmo, yo estoy dispuesto a adquirir cuantas cédulas personales su excelencia quiera» ${ }^{67}$.

En España no sólo encontraban apoyo y complicidad los monárquicos allí refugiados, también los republicanos españoles ofrecían su colaboración al gobierno de Lisboa para el control y la denuncia de las actividades desarrolladas por los contrarrevolucionarios contra la República como el mencionado Eduardo Barriobero.

Ya nos hemos referido a los meses críticos que vivía Portugal en la primavera y verano de 1919, con numerosas huelgas causadas por un movimiento obrero estimulado por la difícil situación económica que vivían las clases populares, debido a los efectos de la Primera Guerra Mundial, y de la ola revolucionaria que barría Europa de Este a Oeste; paralelamente, al riesgo que suponía la emigración monárquica, se le añadía el peligro revolucionario de los seguidores de Sidónio Pais.

El temor se fundamentaba en informaciones como la suministrada por el comandante militar de Valença, teniente coronel Soares, que ponía en guardia a sus superiores sobre la posibilidad de que si estallase un golpe sidonista en Portugal con el apoyo de miembros del ejército, en ese momento, de forma simultánea los exiliados realistas entrarían en Portugal para colaborar en la lucha contra el enemigo común democrático. La información coincidía con los rumores aparecidos en la prensa y manifestados por el presidente Sá Cardoso; la temida pinza monárquico-sidonista, a la que se le añadía la efervescencia operaria, parecía retornar amenazante para los partidarios de A Nova República Velha como había sucedido en 1917.

Aunque, el 20 de julio de 1919, llegaba a Lisboa desde Chaves un mensaje de tranquilidad según el cual parecía que la situación se mostraba más calmada, a tenor de la carta remitida por el comandante del servicio de vigilancia fronteriza, Francisco Rodrigues Pereira, a la Secretaría de Guerra. La información manejada por el militar había sido suministrada por correo por un colaborador republicano español llamado Antonio Nobrega. En la carta, fechada el 16 de julio de 1919 en Feces de Abaixo, pueblo orensano cercano a la «raia», Antonio Nobrega da cuenta del viaje realizado a Orense, concluyendo que de sus averiguaciones, por el momento los exiliados no pretenden realizar ninguna incursión armada en suelo portugués, todo lo más aguardan una amnistía que les permita volver a sus hogares. El único peligro del que ha tenido conocimiento, tras escuchar en un café de Allariz una conversación entre vecinos, es el de la existencia de «agentes bolche-

67 AHDMAE. Legação de Portugal em Madrid. Caixa 143. Maço 5. Despacho confidencial n. ${ }^{\circ} 67 / 919$. Del Consulado de Portugal en Tuy para el agregado militar de la embajada de Portugal en Madrid, 27 de junio de 1919. 
vistas» en las provincias de Pontevedra y La Coruña intentando la compra de armas para realizar una revolución en Portugal ${ }^{68}$.

Sin embargo, esta sensación de sosiego no era más que un frágil espejismo que, una vez disipado, daba paso de nuevo a la inquietud alimentada por las preocupantes noticias llegadas desde España que eran recogidas por los diarios de Lisboa. En el mismo mes de julio de 1919, Padilla daba cuenta de la alarma suscitada en el gobierno republicano por la noticia aparecida en el diario español «El Sol», reproducida en los medios lusos, que alertaba sobre la posibilidad que el amenazante espectro de la revolución monárquica tomase cuerpo, justificándolo en informaciones en base a las que el periódico de Madrid aseguraba que se tramaba «una nueva intentona monárquica en Portugal; así parecen confirmarlo, al menos, las noticias que circulan en Verín, Valença do Minho y Tuy» ${ }^{69}$.

El embajador español trataba de desmentir los insistentes rumores, malintencionados o no, que se propagaban en la zona fronteriza galaico-miñota y que suponían nuevos requerimientos de explicaciones por parte del gobierno republicano que veía con inquietud las maniobras del exilio realista en el país vecino que parecían adquirir una dimensión preocupante y nada desdeñable a tenor de lo publicado pues, al parecer, "en Tuy y Verín hay 5.000 monárquicos y que desde Madrid tienen los fondos para una nueva intentona» ${ }^{70}$. Los datos aportados por «El Sol» eran tan precisos que incluso incluían los emolumentos que percibían según el escalafón los militares exiliados en España: "coroneles, 10 pesetas; comandantes, 9; capitanes, 8; tenientes, 7; alféreces, 6; primeros sargentos,5; ídem segundos, 4; sin graduación y civiles,2,50; a los que desempeñaron el cargo de alcalde durante el breve período monárquico, 8 pesetas ${ }^{71}$. Teniendo en cuenta la cifra de aproximadamente 5.000 refugiados y las cantidades citadas parecía que la organización clandestina en España contaba «con cuantiosos fondos» 72

La información que recibía Portugal, bien en prensa, bien a través de los servicios de información del Ministerio de la Guerra sobre la actividad contrarrevolucionaria de la hueste manuelista en España eran transmitidas al gobierno de Madrid a lo largo de una cadena cuyo primer eslabón era la embajada española en Lisboa, cuyo titular, Alejandro Padilla, las remitía al Ministerio de Estado que hacían que su titular, González Hontoria, a su vez pusiera sobre aviso al ministro de Gobernación, Antonio Goicoechea, para incidir en las consecuencias negativas que podrían acarrear para las relaciones entre hispano-lusas «la campaña que algunos periódicos portugueses realizan queriendo demostrar que en España se

\footnotetext{
68 AHM. Lisboa,1.․ Divisão, 37 Secção, Caixa 51, Maço 2. Teniente Francisco Rodrigues Pereira, comandante del puesto fronterizo $\mathrm{n} .{ }^{\circ} 4$ de Chaves (20-07-1919).

${ }^{69}$ EL SOL, «¿Una nueva intentona?», 20 de julio de 1919.

70 AMAAEE, H-2643. Telegrama cifrado. 26 de julio de 1919. Ministro de España en Lisboa a Ministro de Estado.

${ }^{71}$ EL SOL, «¿Una nueva intentona?», 20 de julio de 1919.

72 ídem.
} 
conspira contra el régimen establecido en Portugal»> ${ }^{73}$. Normalmente las denuncias desde la prensa escrita venían a coincidir en «que los monárquicos portugueses trabajan sin temor en contra del régimen establecido en Portugal, refugiados en España y aprovechándose de varias circunstancias entre las cuales se señala la abundancia de dinero que reciben de los Bancos de Bilbao y la complacencia que con ellos han tenido algunas personalidades oficiales. Se dice también que los conspiradores en Galicia se muestran agitadísimos y que varios de ellos vienen muy a menudo a Madrid para recibir las órdenes de Paiva Couceiro que se encuentra en la capital dirigiendo estas maniobras» ${ }^{74}$. Por tanto, la libertad de movimientos y la disposición de cuantiosos recursos a través de entidades financieras españolas eran una de las claves para dar oxígeno al movimiento antirrepublicano.

Toda esta intensa actividad, real o fruto de la rumorología, desplegada por los exiliados monárquicos en Galicia, obligará también al gobierno republicano a reforzar la vigilancia fronteriza para controlar en lo posible la circulación de este colectivo y personas afines al mismo entre España y Portugal y sus actividades en suelo español, la Secretaría de Guerra para ello no escatimará en medios. Se amplió la red de vigilancia fronteriza con nuevos puestos de vigilancia como el puesto número 17 de Caminha, creado en julio de 1919, debido «... al gran número de conspiradores monárquicos que existen en numerosas poblaciones españolas...» 75 .

\section{LA CONNIVENCIA DE LAS AUTORIDADES ESPAÑOLAS CON LOS EMIGRADOS MONÁRQUICOS: EL CASO D'ESPEDRIGUEIRA}

Como ya se ha referido, la libertad de movimientos del exilio realista en territorio español constituirá motivo de alarma en las autoridades republicanas, que observaban con indignación cómo tenían sólidos apoyos en suelo gallego para lo cual contaban con la ayuda «incluso de las influencias locales que desde 1911 les protegen, tratan de burlar las leales y terminantes declaraciones de V.E., firmemente expuestas en repetidas veces, no desistiendo de su propósito de concentrarse en las proximidades de la República portuguesa» ${ }^{76}$, extremo que el gobierno español trataba de relativizar.

Pero no hay duda que el exilio monárquico en España contaba con la simpatía y complicidad de ciudadanos españoles de cierta relevancia social a nivel local. De ello quedan testimonios en los archivos españoles que prueban los vínculos que el

73 AMAAEE, H-2643, 27 de mayo de 1919. Ministro de Estado a Ministro de la Guerra.

74 Ídem.

75 AHM. Sequeira, A. Jefe del gabinete de la Secretaría de Guerra (24-07-1919). Lisboa, 1.ํDivisão, 37 Secção, Caixa 51, Maço 2.

76 AMAAEE, H-2643. 15 marzo de 1919 Ministro de Portugal en Madrid a Ministro de Estado. 
colectivo de emigrados tenía con destacados miembros de la sociedad española debido a una variada gama de motivaciones (políticas, sociales, económicas o simplemente viejas amistades), en virtud de las cuales, se producían numerosos gestos y acciones solidarias para evitar las severas medidas de control e internamiento que el gobierno de Madrid quería imponer a los refugiados portugueses.

Ejemplo de ello lo tenemos en el caso del general español Máximo Ramos Orcajo, al que unía una vieja amistad con Manuel de Espedrigueira, de cuya ayuda se conserva una copia de una carta del general dirigida a su amigo, el exiliado Manuel de Espedrigueira e Oliveira, que había intentado hacerse valer de la amistad que le unía al militar español para evitar los rigores del internamiento ordenado para él y los suyos. En la misiva, Máximo Ramos, residente en la calle Serrano de Madrid, le expresa a su amigo luso el «gran placer al recibir su carta del 9, por ver en ella que la mediación de mi amigo el Jefe de orden público ha dado los resultados que yo me esperaba y que ustedes pueden continuar en esa ${ }^{77 \text { ». }}$

Al parecer ese enigmático «en esa», según el apunte del ministerio, se refiere a la ciudad de Vigo. Por lo tanto, inferimos de la discreta epístola del general que este medió con un alto cargo (su amigo el Jefe de orden público) para conseguir que De Espedrigueira y su familia pudiesen eludir la orden de internamiento para continuar viviendo en Vigo, si cabe la ciudad que contaba con mayores comodidades de las más cercanas a la frontera portuguesa; lo que le hacía ser uno de los destinos más codiciados para el exilio monárquico puesto que, como reconocía un realista en una carta enviada a un compañero de Monforte que había sido interceptada por el cónsul de Vigo, en la ciudad a orillas del Atlántico «estaría mejor (que en Monforte de Lemos) y con casi la garantía de no salir de Vigo, debido a contar los monárquicos con la influencia de cierta persona» ${ }^{78}$.

Además Ramos Orcajo da una serie de recomendaciones a su protegido para mantener la máxima discreción y no despertar sospechas, dado que se había beneficiado de un claro trato de favor, pidiéndole «que no intervenga ni se mezcle en nada de política de su país para no llamar la atención respecto al favor recibido y poder pasar perfectamente desapercibidos, sin lo cual toda la intervención quedaría sin efecto y su situación sería peor que la de los demás emigrados». Aprovecha el militar español para hacerle llegar noticias de sus allegados, participándole que «de su padre de usted he tenido carta y también de Silva Campos. Todos están buenos» 79 .

Las quejas del gobierno portugués sobre este asunto pronto dieron sus frutos y el Ministerio de Gobernación, a instancias del Ministerio de Estado, ordenó a través de un telegrama al Gobernador Civil de Pontevedra que realizase una in-

\footnotetext{
77 AMAAEE, H-2643. 12 marzo de 1919 Ministro de Portugal en Madrid a Ministro de Estado.

78 AHDMAE. Consulado de Vigo. Caixa 612. Despacho no 6,1919. Del Consulado de Portugal en Vigo al Ministro de Assuntos Estrangeiros, 12 de marzo de 1919.

${ }^{79}$ AMAAEE, H-2643. 12 marzo de 1919 Ministro Portugal en Madrid a Ministro de Estado.
} 
vestigación sobre la situación de De Espedrigueira (también citado en la documentación como Espregueira Oliveira). Tras realizar las pertinentes averiguaciones, realizadas por Julio Salgado, presidente interino de la Audiencia Provincial, el gobernador civil confirmó la presencia en Vigo del exiliado portugués debido «a las indicaciones hechas por la Dirección General de Seguridad a mi antecesor y por este transmitidas al Jefe de Vigilancia de Vigo, que es por completo ajeno a toda protección por iniciativa propia y parece ser, según documentos que tengo a la vista y puedo remitir a V.E., que quien gestionó en Dirección Seguridad esa excepción fue D. Máximo Ramos, que es íntimo del interesado portugués»80. De nada sirvieron a De Espedrigueira las gestiones realizadas por su amigo español Ramos Orcajo, finalmente fue ordenado su inmediato internamiento, tal era el interés del gobierno por «complacer los deseos expresados por el representante de Portugal en esta Corte» 81 .

No queda duda del trato de favor, a través de las poderosas influencias en el aparato de seguridad del general Ramos, recibido por De Espedrigueira que eludía la orden de internamiento; algo que, como reconocía el propio Gobernador Civil de Pontevedra, no era puntual ni se restringía a importantes contactos en la Administración pues también las «órdenes de internación de portugueses que asilan en Vigo tropiezan con decidida protección de fondistas e industriales que piden y obtienen para sus huéspedes de tal clase de la Alcaldía, contra las cuales adopta constantemente medidas este gobierno» 82.

Otra de las razones que hacían del colectivo emigrado monárquico un negocio lucrativo, gozando por ello de apoyos locales, era la posibilidad de facilitar su traslado a Brasil a través de algunas de las compañías navieras que organizaban viajes transoceánicos ya que la emigración gallega a América había hecho de Vigo el principal puerto base del noroeste español. Constataba Alberto Oliveira, cónsul de Portugal en Vigo, la mayor facilidad que tenían los exiliados indocumentados para viajar a Brasil en compañías españolas que, por ejemplo, sobre compañías holandesas que también operaban en Vigo ya que «los emigrados monárquicos dicen que la Compañía Trasatlántica Española, de la que es agente el marqués de Riestra, no será tan rigurosa»83.

Pero no sólo eran españoles los beneficiarios de este tráfico humano clandestino, Oliveira también se quejaba de sus paisanos. Ponía el ejemplo de «barqueros que en el Miño transportan hombres y mujeres indocumentados, de Portugal a España, a cambio de grandes cantidades de dinero» ${ }^{84}$. Un negocio en el que

\footnotetext{
80 AMAAEE, H-2643. 29 de marzo de 1919 Gobernador Civil de Pontevedra a Ministro de la Guerra.

81 AMAAEE, H-2643. Telegrama cifrado. 9 de abril de 1919 Ministro de Estado a Ministro de la Guerra.

82 Ídem.

83 AHDMAE. Consulado de Portugal en Vigo a Ministro dos Negocios Estrangeiros. Vigo, 12 de marzo de 1919. «Consulado de Vigo». Caixa 612. Ano 1919.

${ }^{84}$ AHDMAE. Consulado de Portugal en Vigo a Ministro dos Negocios Estrangeiros. Vigo, 14 de mayo de 1919. «Consulado de Vigo». Caixa 612. Ano 1919.
} 
también participaban los guardias fronterizos portugueses como sucedía «en el puesto de Friestras, donde es comandante el guarda fiscal António Rodrigues, (donde) son frecuentes estos casos, siendo participantes en esos negocios los propios guardias fiscales» ${ }^{85}$.

Se trataba, pues, de un entramado de intereses recíprocos en el que se mezclaban las ventajas que traía aparejado para la hostelería de las localidades gallegas la presencia de cientos de refugiados monárquicos, la mayoría de clase media y alta, y, se supone, que con recursos para hacer frente a los gastos de alojamiento. Por otra parte, las afinidades ideológicas donde las convicciones monárquicas y religiosas unían a españoles y portugueses facilitaban una corriente de solidaridad y simpatía de los primeros hacia sus vecinos; sin olvidar las razones más prosaicas como el beneficio mutuo que podía reportar el lucrativo negocio del contrabando, o la venta de pasajes a Brasil.

Además, parecía que de forma en exceso reiterada, el celo de las fuerzas de seguridad española era cuando menos deficiente y sesgado. El trato benévolo dispensado a los refugiados realistas por las autoridades españolas queda confirmado en una nota del 4 de marzo enviada al jefe del Estado Mayor de la 5. ${ }^{a}$ División, mayor Enrique Pires Monteiro, por el comandante militar de Valença. En dicha nota se registran las quejas por la prohibición de acceder al territorio español a los militares portugueses que cruzan la frontera por parte de la Guardia Civil lo que para el mayor Pires Monteiro suponía un trato discriminatorio «el procedimiento de la Guardia Civil que tan riguroso es ahora para los documentos de los portugueses, era de una absoluta benevolencia y daba todas las facilidades a los rebeldes monárquicos[...]” ${ }^{86}$. El origen de esta medida restrictiva parece diferir según las versiones, en unos casos la justificación de tal medida parece estar en los incidentes causados por los militares portugueses al presentar una conducta impropia de su condición y según otros casos el origen de los desórdenes está causado por las provocaciones que comerciantes refugiados monárquicos dirigían a los militares de la República que visitan España.

Desde Madrid la irritación que provocaba el benévolo trato dispensado a los exiliados era manifiesta con telegramas, dirigidos a los gobernadores civiles de las provincias fronterizas, en los que se insistía en cumplir las órdenes del gobierno de forma tajante y sin contemplaciones ya que "que los monárquicos portugueses aparentando cumplir órdenes de internación, regresan pocos días después a los mismos puntos u otros inmediatos donde antes residían, para lo cual cuentan con la pasividad de los Alcaldes. Reitero a V.S. una vez más la absoluta necesidad de impedir a todo trance y sin contemplación alguna la estancia y presencia en esa provincia de emigrados portugueses, debiendo darme cuenta de que así lo hará

85 Ídem.

${ }^{86}$ AHM. Mayor Enrique Pires Monteiro, Jefe del Estado Mayor 5. a División (04-03-1919). Lisboa, 1.- Divisão, 37 Secção, Caixa 51, Maço 2. 
cumplir». Como muestra de la simpatía que encontraban los emigrados el mismo telegrama incluía, en tono de reproche, una información que había llegado al ministerio de haberse presentado ante el Gobernador Civil de Pontevedra «una comisión compuesta de Don José Herraiz Ruibal, Conservador del Catastro, Don José Sarmiento Ozores, Diputado Provincial y Don Rafael Rodríguez Urbano, Teniente de la Guardia Civil para afirmarle bajo palabra que los emigrados portugueses de esa provincia no conspiraban, siendo falso todo lo que se asegura en contrario. También ruego a V.S. que sobre este extremo se sirva informarme» 87 .

Extremo que sería rechazado por el Gobernador de Pontevedra pero reconociendo a la vez que «es cierto que se han dado algunos casos de regresar pasados algunos días a los mismos pueblos los internados, pero al notarse su presencia han vuelto a ser alejados y dieron como razón (de ) su conducta que la proximidad les daba facilidades para recibir pedidos subsistencias de sus familias» ${ }^{88}$. Además aseguraba que a quien más beneficiaba la presencia de los emigrados era a los hoteleros de la zona ${ }^{89}$, y la presión que ejercían sobre los alcaldes por los pingües beneficios que les reportaba el alojamiento de los exiliados hacía que aquellos no prestasen «toda la cooperación necesaria»90.

El cuestionamiento del celo en el cumplimiento de lo pactado con el gobierno portugués, en cuanto al control de los exiliados manuelistas en tierras españolas, se repetía con demasiada frecuencia tras la derrota monárquica lo que ponía en delicada posición al eficiente embajador Padilla que no cejaba en su «labor de tratar de convencer a este gobierno (portugués) que el de Su Majestad pone de su parte todos los medios posibles y legales a su alcance para evitar manejos políticos que puedan perturbar la tranquilidad interior»91. Pero al parecer la indolente operatividad española no era, al menos en su totalidad, por el escaso entusiasmo prestado por las autoridades locales que debían ejecutar las órdenes del gobierno, sino también era fruto de la escasa disponibilidad de recursos para proceder al internamiento de los refugiados como justificaba el Gobernador Civil de Pontevedra al Ministro de Gobernación en relación a los incidentes del consulado de Tuy.

Las estratagemas empleadas por los refugiados políticos para evitar el cumplimiento de las órdenes de internamiento eran variadas; por ejemplo, solicitaban pasaportes en los consulados de Portugal existentes en las localidades fronterizas,

\footnotetext{
87 AHN. Fondo del Ministerio de Gobernación. «Portugal 1919» LEGAJO 48-A n. 9. Telegrama oficial n.ำ 1457 (30 de mayo de 1919) (Expediente n.ำ15). Ministro de la Gobernación a Gobernador Civil Pontevedra.

88 AHN. Fondo del Ministerio de Gobernación. «Portugal 1919» LEGAJO 48-A n.ำ 9. Telegrama oficial n.ำ 2284 (30 de mayo de 1919) (Expediente n.ำ15). Ministro de la Gobernación a Gobernador Civil Pontevedra.

89 Ídem.

90 AHN. Fondo del Ministerio de Gobernación. «Portugal 1919» LEGAJO 48-A n.ำ 9. Telegrama oficial n.ำ 603 (6 de octubre de 1919) (Expediente n.ำ15). Gobernador Civil Pontevedra a Ministro de la Gobernación.

${ }_{91}$ AMAAEE, H-2643. 3 de junio de 1919 Ministro de España en Lisboa a Ministro de Estado.
} 
con el pretexto de emigrar a Brasil (cosa para la que las autoridades consulares no ponían impedimento alguno si con ello se conseguía alejarles lo más posible de Portugal). El problema venía cuando en realidad, en lugar de embarcar hacia Brasil, acababan permaneciendo «en sitios próximos a la frontera, con pretexto de esperar medios de transporte por mar», lo que hacía que persistiese el quebradero de cabeza para las autoridades portuguesas que cursaban la recomendación al gobierno español para que «no tengan validez dichos pasaportes después de quince días de su fecha y menos para justificar su permanencia, ya que la idea que motivó la concesión fue alejar a esos portugueses, y en modo alguno garantizarles la permanencia en sitios donde con más facilidad puedan conspirar contra la tranquilidad de la vecina República. En su virtud deberá V.S. Disponer que todo portugués que tenga pasaporte de más de 15 días de fecha salga inmediatamente de esa provincia, sin que pueda ir a ninguna otra fronteriza».92

Por su parte, desde el lado español las autoridades también denunciaban el exceso de celo de los cónsules portugueses a la hora de informar sobre las actividades desarrolladas por los emigrados monárquicos «sin duda para hacerse más gratos a su Gobierno, para acreditar servicios, tienen emprendida verdadera persecución a los monárquicos que no les son gratos mientras que a otros les facilitan cédulas consulares para residir, o documentos que justifican su permanencia en expectación de embarque para Brasil en buques que no Ilegan. La colonia portuguesa en la provincia es muy numerosa y si los Cónsules señalasen sin apasionamientos cuales eran los verdaderos conspiradores se simplificaría y haría más eficaz la labor de mis subordinados en este asunto en el que procuraré se cumplan las instrucciones ${ }^{93}$.

Este exceso de celo, que sin duda existía, obligaba en numerosas ocasiones a los gobernadores civiles a desarrollar una investigación para descartar la existencia de supuestos núcleos conspirativos contrarrevolucionarios. Así, en los últimos días de la Monarquía del Norte, el Gobernador Civil de Badajoz respondía al Ministerio de Gobernación sobre la posible existencia de uno de esos centros conspirativos en Badajoz, asegurando que «practicadas las averiguaciones oportunas resulta no ser exacto que la cochera de la calle Gabriel de esta capital sea un Centro de conspiración de portugueses» ${ }^{94}$ pues la razón que había para que en tal lugar acudiesen ciudadanos portugueses era que la propietaria de la casa y que vivía en uno de los pisos era «una española que estuvo casada con un portugués vecino de la inmediata ciudad de Elvas donde tiene la mayor parte de su

\footnotetext{
92 AHN. Fondo del Ministerio de Gobernación. «Portugal 1919». LEGAJO 48-A n. 9. Telegrama oficial n.ำ 1528 (31 de mayo 1919) (Expediente n.ำ1). Ministro de la Gobernación a los Gobernadores Civiles de las provincias fronterizas con Portugal.

93 AHN. Fondo del Ministerio de Gobernación. «Portugal 1919». LEGAJO 48-A n. 9. Telegrama oficial

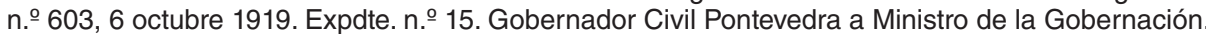

94 AHN. Fondo del Ministerio de Gobernación. «Portugal 1919» LEGAJO 48-A n.ำ 9. Telegrama cifrado $n$. ㅇ 386 (9 de febrero 1919) (Expediente n.ำ2). Gobernador Civil Badajoz a Ministro de la Gobernación.
} 
capital y reside con más frecuencia que en esta. Los demás pisos de dicha casa están habitados por vecinos que no tienen relación alguna con portugueses y manifiestan no haber observado nada que llame su atención. Frecuentemente vienen de la inmediata ciudad de Elvas a las funciones de teatro y cine de esta capital, portugueses que por su amistad y conocimientos con la propietaria de la casa de la cochera aludida, entran en esta hasta su regreso los coches donde vienen y esto puede haber motivado aquella suposición» 95.

Aún así no dejaba de reconocer el gobernador que en las localidades de esa provincia vivían «portugueses lo mismo monárquicos que republicanos, unos que han tomado parte en los sucesos políticos de su Nación y han venido huyendo y otros que por su significación política no pueden permanecer en aquella,» pero no representaban un peligro para la estabilidad del país vecino pues «se ocupan seguramente de los asuntos de su país, pero en forma platónica, porque carecen de medios para actuaciones más activas» ${ }^{96}$. Lo que no significaba que se bajase la guardia y que desde el Gobierno Civil se ordenase que estuviesen constantemente bajo control y por si no fuera poco si se creyese conveniente y «para evitar torcidas interpretaciones dispondré que se internen aquellos que parezcan más significados. ${ }^{97}$ 》

\section{DISENSIONES EN EL COLECTIVO EXILIADO: LA DIATRIBA ENTRE PAIVA COUCEIRO Y EL CONDE PENELA}

Los problemas que causaban los refugiados realistas no sólo tenían su origen en los enfrentamientos con sus compatriotas republicanos sino que, en ocasiones iban más allá, llegando a la confrontación entre miembros del colectivo monárquico, fruto de las disensiones internas existentes en el movimiento azul y blanco. Un ejemplo de estas diferencias internas fue el conflicto que se desarrolló en el verano de 1919 donde, a través de la prensa, se dirimió una agria polémica entre Paiva Couceiro y el conde Penela a raíz de unas declaraciones del primero en el diario español «El Sol» sobre los acontecimientos de los que fue protagonista durante la revuelta que dirigió en Oporto.

Las declaraciones de Paiva fueron contestadas por el conde Penela, exiliado en Vigo, a través de las páginas del diario local olívico «La Concordia» desde las que lanzaba un duro ataque contra el líder de la «Monarquía del Norte» al que despectivamente trata como «ex capitán Paiva Couceiro, hecho por sí mismo coronel la última vez que se puso al frente de los monárquicos portugueses, o sea

\footnotetext{
95 Ídem.

96 AHN. Fondo del Ministerio de Gobernación. «Portugal 1919» LEGAJO 48-A n.ำ 9. Telegrama cifrado $n .{ }^{\circ} 386$ (9 de febrero 1919) (Expediente $n .{ }^{\circ}$ 2). Gobernador Civil Badajoz a Ministro de la Gobernación.

97 Ídem.
} 
cuando provocó la revolución de Oporto el presente año» ${ }^{98}$. El conde Gomes de Penela, abiertamente partidario de la línea oficialista del realismo portugués, precisaba que la mala dirección de la insurrección fue debida a que «Paiva no posee ninguna de las cualidades que precisa tener un jefe capaz de restaurar el régimen monárquico en Portugal»>99; además estaba en desacuerdo con las afirmaciones hechas por el líder realista en las que se tenía por persona de gran iniciativa, poder y popularidad en Portugal para sentenciar que tal popularidad tan sólo era debida «a haber manejado los fondos que le fueron confiados».

Penela critica la importancia que Couceiro otorgaba a la posibilidad de convocar un plebiscito en Portugal para resolver la cuestión del régimen pues «tal declaración no responde a la verdad de su sentimiento, porque Paiva pudo verificar el plebiscito hace pocos meses»; en lugar de ello Penela le afeaba el abanderar el estallido de la insurrección de modo que «para eso no hizo plebiscito el capitán Paiva Couceiro» ${ }^{100}$. Para Penela el aparentemente errático comportamiento de Paiva Couceiro no era más que una actitud malintencionada pues «en el fondo de todo esto hay un pensamiento oculto de mala voluntad contra el ex Rey, porque el soberano destronado no acudió a Oporto al estallar el movimiento» ${ }^{101}$. Así, lo que para Paiva Couceiro había sido determinante para el fracaso de la insurrección (la negativa de D. Manuel a retornar a Portugal para liderar la revuelta y aunar el apoyo del mayor número de simpatizantes posibles a la causa restauracionista incluido el apoyo exterior), para los miembros de la línea oficialista que marcaba el propio soberano, no había sido más que una sabia decisión para mantenerse al margen de aventuras arriesgadas que ponían en riesgo la estrategia de esperar al derrumbe de un régimen republicano que ya daba signos de agotamiento.

Penela continuará en días posteriores atacando a la figura de Paiva Couceiro desde las páginas de "La Concordia», incidiendo en evidenciar que «el ex capitán Paiva Couceiro ha manejado, y está manejando, el dinero que le fue entregado, o del que pudo apoderarse recientemente en el país y lo destina a cosas que le son agradables, y no a las cosas que debiera» 102 . Para fundamentar tal acusación el conde Penela recurre a las revelaciones que le hizo un comerciante español, dignas de crédito, pues se trataba de un profesional establecido en Portugal desde hace años, según las cuales «durante la revolución monárquica de enero, las sucursales del Banco de Portugal en Oporto y otras ciudades del norte sufrieron enormes desfalcos. En Oporto, fue tan elevada la suma de que se apoderaron los monárquicos, que la Dirección del Banco adoptó el acuerdo de no revelarla, para no alarmar a la opinión» ${ }^{103 .}$.

\footnotetext{
98 «El Sol». «Los monárquicos portugueses a la greña», 2 de julio de 1919. Pág. 3.

99 Ídem.

100 Ídem.

101 Ídem.

102 «El Sol». «Los monárquicos portugueses a la greña», 4 de julio de 1919. Pág. 2.

103 «El Sol». «Los monárquicos portugueses a la greña», 4 de julio de 1919. Pág. 2.
} 
Y para afear todavía más la responsabilidad de Paiva Couceiro en la malversación de los fondos incautados por la fuerza en los bancos del norte de Portugal por las fuerzas militares a su servicio ofrece un nuevo testimonio, en este caso, del oficial monárquico Cardoso Menéndez, hijo del conde Margaride, ex comandante refugiado en Holanda, que le había confiado otra turbia historia relacionada con el uso fraudulento de una elevada suma de dinero requisada por el mayor Rangel en Vila Real donde se encontraba con su «Columna Relámpago» cuando conoció la victoria republicana.

Rangel «como carecía de recursos para conducir sus tropas a la frontera, acudió a la sucursal del Banco en Villarreal y pidió un millón de pesetas. La suma fuéle entregada, por haber apelado a la fuerza, y porque dio a cambio de ella un recibo, en el que se comprobaba la manera en que se apropió de ella». Una vez que atravesó la frontera y se internó en territorio español con sus hombres y el dinero, se trasladó a Madrid para entrevistarse con Paiva Couceiro a quien dijo «que era voluntad suya inflexible el entregar el dinero al ministro plenipotenciario de Portugalı ${ }^{104}$. Cuenta Penela que Couceiro se opuso de forma tajante a tal iniciativa y «tras violenta escena, acordaron depositar el dinero en un Banco» ${ }^{105}$.

Vanagloria infundada, malversación de fondos, mala fe, infidelidad a la causa monárquica, todo al servicio de la ambición desmedida de Paiva quien además «motu proprio» se ascendía a coronel. Las acusaciones vertidas por Penela eran de tal calibre que presagiaban un desenlace de cualquier naturaleza menos pacífico. El enfrentamiento al realizarse a la luz de la prensa adquiría para los lectores de «La Concordia» y «El Sol», este último uno de los diarios españoles más leídos en Portugal, los tintes de una animada novela folletinesca que todavía ofrecería nuevas entregas.

Uno de los aludidos, el mayor Joaquim César Rangel, con premura se dispuso a ofrecer su versión de los hechos a través de una carta enviada a «La Concordia» para aclarar las manifestaciones referidas a su persona por el conde Penela (que al igual que a su superior Paiva no le dejaban en buen lugar). Sin embargo, su versión de los hechos distaba de la del aristócrata, pues como aseguraba: «El 15 de febrero saqué de la Caja del Banco de Portugal en Braganza, cien contos de reis, para atender a los gastos de las fuerzas que tenía el honor de mandar. La víspera de nuestra retirada para España, entregué en la Caja Económica de la misma ciudad sesenta contos de reis. Los cuarenta contos restantes fueron administrados por el Consejo de la Columna, bajo mi presidencia, con arreglo a las leyes y reglamentos militares, resultando un saldo de más de diez y seis contos, cantidad que, por acuerdo del mismo Consejo, fue entregada con sus justifican- 
tes, al coronel Paiva Couceiro, presidente de la Junta Gubernativa, única autoridad reconocida por la Columna» 106.

Por tanto, si creemos en la información ofrecida por Rangel, el uso del dinero ni fue tan cuantioso ni resultó ser tan sospechoso pues el oficial aseguraba que «los acuerdos del Consejo no se tomaron bajo la presión de Paiva» (aunque sí es cierto que se llevó a España una importante cantidad). Para Rangel las discrepancias surgidas entre los exiliados expuestas públicamente no le resultaban en absoluto de su agrado ya que en su opinión era «lamentable que entre los portugueses emigrados se entablen discusiones de esta naturaleza, cuando debiéramos anteponer a todo el interés supremo de la patria y de la Monarquía»107.

Pero esta polémica no acabó en un debate circunscrito a las páginas de los diarios españoles sino que fue más allá. A los pocos días del escrito de Penela, cuando este salía a las nueve de la noche del Hotel Universal de Vigo donde se hospedaba, vio como avanzaba hacia él en actitud violenta António Calainho, otro emigrado monárquico. El conde, temiendo una agresión, le encañonó con el arma que portaba, advirtiéndole que no siguiese avanzando o dispararía; «como el agresor no desistiera de su actitud, el conde Penela disparó su revólver, hiriendo de un balazo en la región epigástrica a Calainho» ${ }^{108}$. Finalmente el suceso acabó con la detención del conde y una herida sin importancia para Calainho quien poco después declaraba que cuando abordó a Penela su única intención era censurarle la actitud mantenida ante Paiva.

Como vemos, el fracaso de la Monarquía del Norte hizo que las discrepancias internas existentes entre las diferentes sensibilidades ideológicas se transformasen en heridas abiertas cuya única cura parecía ser el abandono del monarquismo oficial e iniciar un proyecto propio, como sucedió con el posterior abandono del movimiento integralista, en desacuerdo con la actuación llevada a cabo por D. Manuel en aras de restaurar la monarquía en Portugal.

\section{CONCLUSIÓN}

En Portugal la azarosa transición de la monarquía a la república, a principios del siglo pasado, estuvo marcada por el acoso con el que las fuerzas realistas trataron de desbaratar al nuevo régimen para conseguir el retorno de los Braganza al trono. De todas las embestidas contra la Primera República, destaca la eclosionada a principios de 1919, que pasaría a la posteridad como la «Monarquía del Norte». Fue sin duda la revuelta que alcanzó mayores visos de poder hacer realidad el ansiado proyecto restauracionista, al conseguir el control del septentrión

\footnotetext{
106 «El Sol». «Los monárquicos portugueses, a tiros», 5 de julio de 1919. Pág. 1.

107 Ídem.

108 Ídem.
} 
luso con la ciudad de Oporto como capital. Sin embargo, tras el fracaso de los insurrectos en Lisboa, el sueño de una vuelta a la monarquía se desvaneció tan rápido como había surgido.

La presente investigación tiene como objetivo primordial plasmar la situación del colectivo de exiliados monárquicos portugueses que, tras la derrota de la Monarquía del Norte en 1919, hubieron de buscar refugio en suelo español. Siguiendo el rastro dejado en archivos de ambas naciones ibéricas y en fuentes periodísticas se ha querido recuperar para la memoria cómo se organizó este colectivo en nuestro país, cuáles eran sus fuentes de recursos, en qué zonas su presencia movía a la preocupación de las autoridades y, por extensión, cómo mediatizaron durante un notable espacio de tiempo las relaciones bilaterales entre España y Portugal, cuyo gobierno mostraba un alto grado de preocupación por las posibles nuevas intentonas contrarrevolucionarias monárquicas que pudieran tener como base y punto de partida el territorio del Reino de España. Sin embargo, con el paso del tiempo, los temores de las autoridades republicanas a nuevas rebeliones promovidas por realistas se fueron disipando. Y así, La «Monarquía del Norte» resultaría la última aventura de los realistas portugueses de carácter restauracionista.

Por otra parte, además de las implicaciones mencionadas en las relaciones internacionales hispano-lusas, otra de nuestras hipótesis de trabajo ha sido reflejar el fascinante cuadro social que, en lugares como el sur de Galicia, se configuró con la presencia de cientos de exiliados que, tratando de burlar las órdenes de internamiento dictadas por los gobernadores civiles, se resistían a abandonar las zonas fronterizas y se ganaban la vida de las formas más variadas, lícitas e ilícitas, entre las que el contrabando era uno de los recursos más socorridos. Muchos, asimismo, han sido los incidentes de orden público provocados por este colectivo en localidades españolas en su confrontación con ciudadanos republicanos portugueses e incluso entre monárquicos de distintas sensibilidades políticas, en los que el recurso a la violencia física con desgraciadas consecuencias no fue algo inusual.

Tras el desastre de 1919, el movimiento monárquico, derrotado y debilitado por las escisiones, pareció convencerse de que la fórmula de un Estado republicano era asumida o tolerada por gran parte de la sociedad, incluidos amplios sectores del conservadurismo antaño afectos al monarquismo, así como de la dificultad para imponer una vuelta de la monarquía. Por tanto, la hueste azul y blanca, salvo un sector minoritario de irreductibles, se resignará a participar en la actividad política del país dentro de la legalidad republicana diluyéndose en el bloque político conservador y priorizando como gran objetivo a conseguir el ofrecer su colaboración para derribar a la Nova República Velha junto a los herederos del sidonismo. Objetivo en el que perseveraron con su colaboración hasta conseguir el éxito del golpe militar del 28 de mayo, preámbulo de la dictadura salazarista.

Por su parte, los emigrados monárquicos en España con el paso del tiempo, como había sucedido con las anteriores intentonas fallidas, se fueron benefician- 
do de una nueva amnistía decretada en enero de 1924 que posibilitó su progresivo retorno a Portugal. Se cerraba así un capítulo de la Historia de los dos países ibéricos vecinos que dio lugar a la presencia de un nutrido colectivo de realistas en Galicia que dejó una apasionante impronta en las áreas fronterizas españolas donde se asentaron y cuya memoria hemos tratado de rescatar a través de estas líneas. 
